\title{
Venice Biennale 2017: Salon des Réfugiés
}

\author{
JAE SON ${ }^{1}$ \\ Mina Cheon (PhD, MFA) \\ Associate Editor, Media-N and Board of Directors, New Media Caucus \\ Full-time Professor, Maryland Institute College of Art
}

\begin{abstract}
This single review of a sprawling international exhibition takes as a conceit the comparison of three Pavilions within the 2017 Venice Biennale - that of Korea, the United States, and Antarctica. The author seizes on the opportunity afforded by the esteemed event's organization around nation-states to reflect on the radical ways in which the exhibited artists are engaged with the distinct challenges and struggles of their respective homes (or non-homes). This essay is therefore an attempt to culturally compare with nuanced interpretation, as a way to stay close to the formation and ramification of world culture today. To diversify the potential in the read, the piece calls to unfold in rhetoric of postcolonial terms, related to new media scholarship.
\end{abstract}

\section{INTRODUCTION}

This essay is clearly biased. A Korean-American writer covers three national Pavilions as a critical comparative analysis of the Venice Biennale 2017: the Korean, the American, and the noman's land, the Antarctic, Pavilions. It is a far stretch to relate the 1863 Paris Salon des Refusés (Salon of the Refused) with these particular Pavilions in Venice this year, accept for the fact that modern art was born out of the rejected paintings of the academic French salons, notably Édouard Manet and James McNeill Whistler, who made their way to supplement a neoliberal imperial cause for Emperor Napoleon III when he opened the exhibition on May 15, 1863. The artists then simultaneously became sensationalists overnight while implanting the seeds of modernism with Le Déjeuner sur l'herbe (1863) and Symphony in White, no. 1: The White Girl (1861-1862); ${ }^{2}$ refused art or art produced in refusal states has the tendency to stir things up, getting rid of the old and starting things anew.

Needless to say, a closer read of these three national Pavilions today - the Korean, U.S., and the Antarctic - necessitates confronting old paradigms of nation-states as hallmarks of glorious biennale tropes, and the individuated abjections, rejections, and refusals of these older paradigms, conflicted by the stubbornness of the regulatory values that keep in tack. Such a read makes for a solid inquiry into the connections and contradictions between the Biennale and the Salon. The conditions of what made Salon des Refusés vital, giving light to the rejects and showcasing alterity as a new platform for change, similarly mark today's Venice Biennale as the catalyst to 
change, remaining meaningful in the rumble and tumble to fit world scenarios and social commentary onto the transitory cultural stomping grounds of the Biennale sites and Pavilions.

A further stretch of the imagination would be to connect the notion of the refusal with the refugee (hence the creative twist in the new title Salon des Réfugiés), bearing in mind that all artists written about here reject this connection from the get-go, but this essay is nevertheless dedicated to unpacking and understanding the idea of refuge and the sites of art that dictate a closer look at our world shaped by permanent state of crisis, emergency, and disarray. Critics may point out the discrepancy between the title and not actually dealing with refugees and Syria, and how the artists are not directly making work about such things, especially compared to other artists in the biennale: Candice Breitz and Mohau Modisakeng's media work in the South Africa Pavilion, which "together form an articulation of our past and current state of refugeeness within a global context of exclusion and transience,"3 and Olafur Eliasson's Green Light workshop, which was done with and for migrants and refugees. ${ }^{4}$

The remnants of a global crisis dealing with mass migration against a backdrop of today's information war breeds a different kind of state of the arts, a peculiar condition reflecting a global state of panic. To be in didactic synchronism, putting migrants and refugees into the same fold may be a self-reassuring ethical stance in writing (or creating art); at the same time, if not done properly, questions of legitimization linger at best. ${ }^{5}$ There are many other ways to tackle the subject; we can find connections in every corner of the world with troubling issues to do with citizenship and naturalization versus migration and diaspora. From there, realities of being exiled, living dissident lives, and struggling as refugees spotlight the critical state of crises we live in.

Lee Daehyung, the curator of the Korean Pavilion, turns our attention to how even Korean problems are global problems to recognize. He mentions that "the crisis in Korea is a concern of Asia and relates directly on a global scale, Korea's concern is the world's concern." Everything is related - this essay however does not try to make it seem like there is a solution or answer to the global refugee problem. It addresses how such problems exist in larger contextual fields and cast contemporary art's unconditional relationship to most great problems in society, intrinsically or extrinsically stated, expressed, or otherwise.

The lay of the land of the art world is flooded with contestable imagery that we don't always know what to do with at most times. Ai Weiwei's 2016 photo rendition of himself as drowned infant Alan Kurdi on the shores of Turkey, which originally was an appropriation of a 2015 journalistic photo of the drowned child washed up on the shores and symbolizing the pinnacle of Syria's refugee crisis, is still raised as a point of the artist's cruelty and bad taste. ${ }^{7}$ The American Whitney Biennale this year includes two works much talked about, even protested against: one, Dana Schutz's painting Open Casket, ${ }^{8}$ a horrific portrayal of Emmett Till in open casket done in globs of paint that the artist just didn't get right, and two, being a little too close to the visualization of an assaulted white male victim in Jordan Wolfson's VR Real Violence (2017). ${ }^{9}$ Seen through the VR helmet with a sound track recitation of a Hanukkah blessing, the adrenalininducing simulated violence piece is confusing but we don't ever get near the subject matter as to why because of the visual trauma we are trying to forget. These controversies stemming from contemporary art worlds, cared for mostly in the art world, are brought up and discussed and many times, nevertheless, some points are never made well on time. Usually, the missed opportunity is in not pinning down the nuances that go along with the cultural analysis - maybe we just don't have time or the attention span for cultural sensitivity, or just don't know how. ${ }^{10}$ 
In Venice, one is recommended not to miss Damien Hirst. But for an artist who obviously is not lacking in resources of any kind, including being celebrated for stealing the identity of a freed slave Cif Amotan II from Anitoch (north-west Turkey) from the mid-first to early second centuries CE and using his treasures and wealth as the inspirational source ${ }^{11}$ of the exhibit, we lose steam, seeing art that is a copy of a copy of a copy as it gets old quick. ${ }^{12}$ We fumble into the Palazzo Grassi and Punta della Dogana of Venice to see Hirst at his plight with "Treasures from the Wreck of the Unbelievable," "13 and sigh, that this is the unbelievable art world - a world of wrecking derivatives.

Where artistic appropriation and pastiche across history, culture, and time can seemingly add something to the discourse of diversity (and hybridity), the results are often about the idiosyncratic mash-ups, folk remixes where everyone and everything is included, gelling Disney and Sea World (as the song is played out in our minds from The Little Mermaid, "Under the sea, Under the sea"). This is not diversity, it is anything goes, lacking real cultural contributions and comparisons for awareness sake. Thanks to recent social uprisings, art as activism, protest and art, inevitably if not tied to social concerns this time, we wonder of this phenomenon's relevance, controversial or not. So, nuance counts, what is the art doing as much as what is it about, how is it activism, and what is the work triggering? Art and activism, activism and art, those two things are very much in alignment together as a powerful communication tool; yet many people do not know how to see these two forces working in necessary tension and stride. ${ }^{14}$ Empathy counts. Yet, there is "Power of Bluff" (Cody Choi) since we ain't got much else going on in this confused forsaken world.

All things however are related to the escalation of the eminent global crisis of hatred, racism, sexism, xenophobia, terrorism, migration, and the refugee crisis amidst the international political divisions during post-capitalism between nationalist ideologies and prodemocracy. Witnessing the Venice Biennale unfold in its array of differences every two years, there is no doubt that it both stages and reflects the latest of the contemporary art world, and also shapes it. Same goes with the reading of the biennale, through reviews, features, and interviews - what gets highlighted and crossed out often helps bring structure and form to a mega international exhibit which is often difficult to digest otherwise. This essay is therefore an attempt to culturally compare with nuanced interpretation, as a way to stay close to the formation and ramification of world culture today. To diversify the potential in the read, the piece calls to unfold in rhetoric of postcolonial terms, related to new media scholarship.

At the $57^{\text {th }}$ International Art Exhibition, the Venice Biennale, curated by Christine Macel "Viva Arte Viva" (Live Art Live, Art is Alive), Macel writes, "Today, faced with a world full of conflicts and shocks, art bears witness to the most precious part of what makes us human, at a time when humanism is precisely jeopardized. Art is the ultimate ground for reflection, individual expression, freedom, and for fundamental questions. The role, the voice and the responsibility of the artist are more crucial than ever, within the framework of contemporary debates." ${ }^{\text {"6 }}$ Macel managed to create "trans-pavilions"17 throughout the Giardini's Central Pavilion and Arsenale and which, dedicated to allowing artists to be full-fledged themselves, artists, to shape their ways, knowledges, intelligence and artistry to partaking in creating houses of healing - Pavilion of Artists and Books, Joys and Fears, Commons, Earth, Traditions, Shamans, Dionysian, and Colors, Time and Infinity. They are quite unusual takes and artistic offerings for what is 
considered the international standard and mark, but they work to hone in on sacredness. The level of mysticism and magic in small things were largely spoken to address global desperations and societal impoverishment. ${ }^{18}$ "If these are the components of our world, or rather, those that Macel sees as central concerns of artists, it's a tentatively optimistic picture that she presents. It amounts to a prescription for a cure, perhaps, to humanity's current ills."19

The Traditions space includes an installation called Janas Code (2016-17) that exudes feminine power containing the spirits of ancient fairies from Domus de Janas (house of the fairies), which were Sardinian burial tomb spaces. Systematically laid out in rows on walls and on bare wooden furniture with warm ceramics, open books, curious artifact-like objects, and woven pattern tapestry, we are assured the exhibited works are the handy craftworks by a woman igniting the spirit of Mediterranean Mother Goddess of life and afterlife, yet caught off guard by our own assumptions of gender even in contemporary times. The body of work delights and surprises us to recognize they were by Michele Ciacciofera who demonstrates the transformative and liminal power of creation that can channel all spirits and worlds, gender and sexes, fairies and witches in a breath of earthly display - since magic is queer. ${ }^{20}$ Lee Mingwei's The Mending Project (20092017) allows the audience to bring a torn up article of clothing that the artist would sew and leave folded on a table with the thread still hanging from the spool. Multi-colored spools are installed all throughout the walls and the threads web through the exhibition space to all the mended clothing. The artist sewing and tying, mending, people's things while conversing personally with the audience is a lovely and generous poetic performance, and a practice counter to the typical masculine robust sculpture-making process. ${ }^{21}$

The identity of a refugee tied to issues of exile, dissident, displacement and migration, is bound to the definition of nationality and nationhood conflicted by its queer status of being in limbo as the undocumented and the indefinable. This spectral range of diaspora and nation exists together, in a hierarchical relation that Gayatri Gopinath read as queer and straight in postcolonial situations that she writes about in Impossible Desires: Queer Diasporas and South Asian Public Cultures. ${ }^{22}$ Gopinath describes how "The patriarchal and heteronormative underpinnings of the term 'diaspora' are evident in Stefan Helmreich's exploration of its etymological roots: The original meaning of diaspora summons up the image of scatters seeds and... in Judeo-Christian... cosmology, seeds are metaphysical for the male 'substance' that is traced in genealogical histories. The word "sperm" is metaphorically linked to diaspora... Diaspora, in its traditional sense, thus refers us to a system of kinship reckoned through men and suggests the questions of legitimacy in paternity that patriarchy generates." 23 Hence, when thinking of refugees, we must understand the larger global and Western power that is refusing these lives. And, also an awareness that we are in dire need of some serious magic today.

Now, curtailing back to the three major pavilions as the site of discussion for this essay - first, Lee Daehyung's Korean Pavilion is chaotic with intentionality. It reflects the chaos of our time, focused on the peninsula and outreaching the connections beyond to the international world stage through a transgenerational strategy exceeding the more familiar transnational rhetoric, newly conjuring a mega hit two-man show by Cody Choi and Wan Lee, and reflecting a passage of time from Korea to the world, and a read that is historical, generational, and towards the future. Two, the American Pavilion that displays relentless US soft power sought after post Obama times, ${ }^{24}$ presents a new timelessness with Mark Bradford referenced as the Jackson Pollock of our time, ${ }^{25}$ and brings out his real strength as the artist's role being citizen first, highlighted by commissioner Chris Bedford. Bradford paves the way for how an individual social activism and artist project 
can make a difference in lives, this time working with existing system of prisons, with Rio Terà dei Pensieri (RTdP), a Venetian organization for rehabilitating prisoners.

Lastly, the Antarctic Pavilion problematizes the meaning of displacement for a group of artists as they are "placed" into the timeless zone of Antarctica, to go boldly where no artist group has gone, led by commissioner Alexander Ponomarev with co-curator Nadim Samman, venturing to no-man's land, of no singular national identity, yet brushing up on a space uniquely laid for ideological frontier of an avant-garde charge and laying the foundation of a future "supranationality (supernational)",26 of artists, inevitably an "art nation" for whom undoubtedly with national representation. In "Apprehensions of Time" of Imagined Communities, Benedict Anderson writes, "Beneath the decline of sacred communities, languages and lineages, a fundamental change was taking place in modes of apprehending the world, which more than anything else, made it possible to "think' the nation." ${ }^{27}$ Thinking the nation is how we understand it to be imagined. The Antarctic Pavilion recounts the expedition to Antarctica, bringing back documents as exhibition, holding fort for the site of an imagined nation.

\section{The Korean Pavilion's Transgenerational Counterbalance between The Stone and The Mountain}

In an interview, ${ }^{28}$ Lee Daehyung, the curator of the Korean Pavilion of the Venice Biennale describes the discrepancy between disregarded things like pebbles and stones versus the mighty mountains that are named and cited in history. The individual stones are dismissed and the memories carried by such debris are never considered, whereas origin stories and myths are created, and surround the mountains, and legends are made and histories are written, never forgotten. Benedict Anderson in Imagined Communities, writing about "The Biography of Nations," says, "Nations, however, have no clearly identifiable birth, and their deaths, if they ever happen, are never natural. Because there is no Originator, the nation's biography cannot be written evangelically, 'down time,' through a long procreative chain of begettings." ${ }^{29}$ He goes onto say those men, "Peking Man, Java Man, King Author," ${ }^{30}$ historic figures are marked by their mythic births and deaths to help establish the legitimacy and identification of forming causality of nations. Similarly, it is the renowned historic sites, ancient ruins, and archeological sites, natural or architectural landmarks, that get promoted as being national treasures, extracted from everyday life. Lee however mentions that between the identities of the stone versus the mountain, both are resoundingly the same, in material, science, and philosophy.

Lee promotes:

Counterbalance: The Stone and the Mountain strives to answer the following question: How do individual stories relate to national histories, How might our understanding of this dynamic in the Korean context be relevant to the rest of the world and shed light on the future? The exhibition is structured around three geographical frames - Korea, Asia, and the world - and three generations of Koreans. Mr. K represents the first generation, Cody Choi the second, and Lee Wan the third. The pavilion's works aim to inspire the imagination and trigger the empathy of diverse audiences. (Counterbalance, exhibition pamphlet, Introduction)

Lee recognizes global hyperconnectivity between societies and how the Korean division between the South and the North as well as the corrupt government on both sides are influencing and 
influenced by global social politics and economics, that from Brexit, Trump, to the French and Korean new elections, each individual's actions count, everyone is accountable and responsible for the outcome of tomorrow. Lee shifts from the multifold of transnational dialogue to emphasize a new kind of transgenerational model of relational structure that caresses the trauma and recuperates transgenerationally. The burden of change, handled singularly in one generation, is then passed down generation to generation, bound to be overcome. The counterbalance between these generations is therefore about forgiveness and while recognizing differences, within the family or country, a united front that puts peace and devotion over anything else that has been the strength of building a modern nation that should not be forgotten. The last 100 years of marked modernization in South Korea include stark changes in the last three generations; while each generation has imparted radical different points of view, the collective model towards peace in family can be applied and understood in larger societal terms. In the pavilion, Cody Choi's disco room installation, Color Haze for example, directly reflects how whatever happens in the club is forgotten and forgiven, whereas in reality, conflicts are everywhere, and that even the nightclub is better than real life today.

Chinese artist Song Dong's "Wu jin qi yong (Waste Not)" (2006) installation, certainly had a strong sense of transgenerational channeling, between his father's death, attending to and mending his mother's needs, assistance, and obsession. The interwoven generational gap was represented in a collaborative accumulation of his mother's hording of materials, even while generationally material goods have new meaning in China. The artist son with his mother in collaboration deals with mourning through the process of making the installation together. ${ }^{31}$ But it is in the more recognized transcendent work beyond the self, such as that of Theresa Hak Kyung Cha and Dictee, ${ }^{32}$ where the self is relocated into other identities across time and space, transmitted into historic and transcultural dimensions. Cha assumes the role of other heroines, her mother, Yu Guan Soon, Joan of Arc, Demeter and Persephone; her literature is a palimpsest of discovery and honoring those female histories not to be forgotten. Moreover, Melissa Chiu in "Theories of Being Outside: Diaspora and Chinese Artists," writes about artist Chen Zhen's notion of "transexperience" as a way of interpreting the trends of Chinese diaspora as returning to the homeland ${ }^{33}$ with great emphasis of how the transexperience points specifically to the notion of change, allowing 'cultural homelessness' and 'belonging' that are multiplicities. ${ }^{34}$

Inderpal Grewel and Caren Kaplan write in Scattered Hegemonies about how uncovering global-local or center-peripheral views in postcolonialism point out the binary structure still remaining in the terrains of Euro-North-American-centricity. Scattered hegemonies of colonial structures all turn to the larger "global-local binaries [which] dangerously correspond to the colonialism-nationalism model that often leaves our various subaltern groups as well as the interplay of power in various levels of social political agendas." 35 Transnationalism can be a force of new strategy, specifically used "to problematize a purely locational politics of global-local or center-periphery in favor of what [Armand] Mattelart sees as the lines cutting across them" and to bring forth how "local subjects are not 'passive receptacles' who mechanically reproduce the 'norms, values, and signs of transnational power." "36 Cultural hybridity reflects the lack of originality of a culture, meaning, "Western culture is not pure," yet in the West, "hybridity" remains enmeshed in the gaze of the West." 37 We see this all the time, as it is very difficult to find moments that are completely removed from the Western perspective and framework.

Gennifer Weisenfeld writes about transnationalism in other ways. In looking at contemporary Japanese art in particular, she shows how the works of Murakami Takashi or Araki Nobuyoshi tie 
Japanese "tradition" such as the Edo period and woodblock prints to the traditions of Ukiyo-e and Shunga found in manga and anime culture dominating modern Japanese culture and the manufactured kawaii (meaning cutsie) scene, and relates to Partha Mitter's point that "neurosis about authenticity [confounded in national tradition] [is] a very nationalist preoccupation all of over the world." 38 Authentic localism finds a footing as a part of the 'artistic nationalism', a conflated universality that tenuously breach transnational ideals and realizes it. The Korean Pavilion can't escape the postmodern methodology of hybridizing East and Western culture, but it certainly doesn't try to present a traditional Confucian, Buddhist Korea to create Koreanness or nationness, but rather show Korea in its raw state today, with brute honesty of its chaos, Western influence as its make-up of culture, K-wave, K-pop, K-suicide club, K-politics, and K-protests; all these things in the Pavilion say a bit more about what is unique to Korea now. ${ }^{39}$

Welcome, Pole Dance, Free Video TV, Free Narcissistic People Disorder

Free Peep Show, Major Credit Cars, Free Orgasm (Choi, Pavilion front sign) ${ }^{40}$

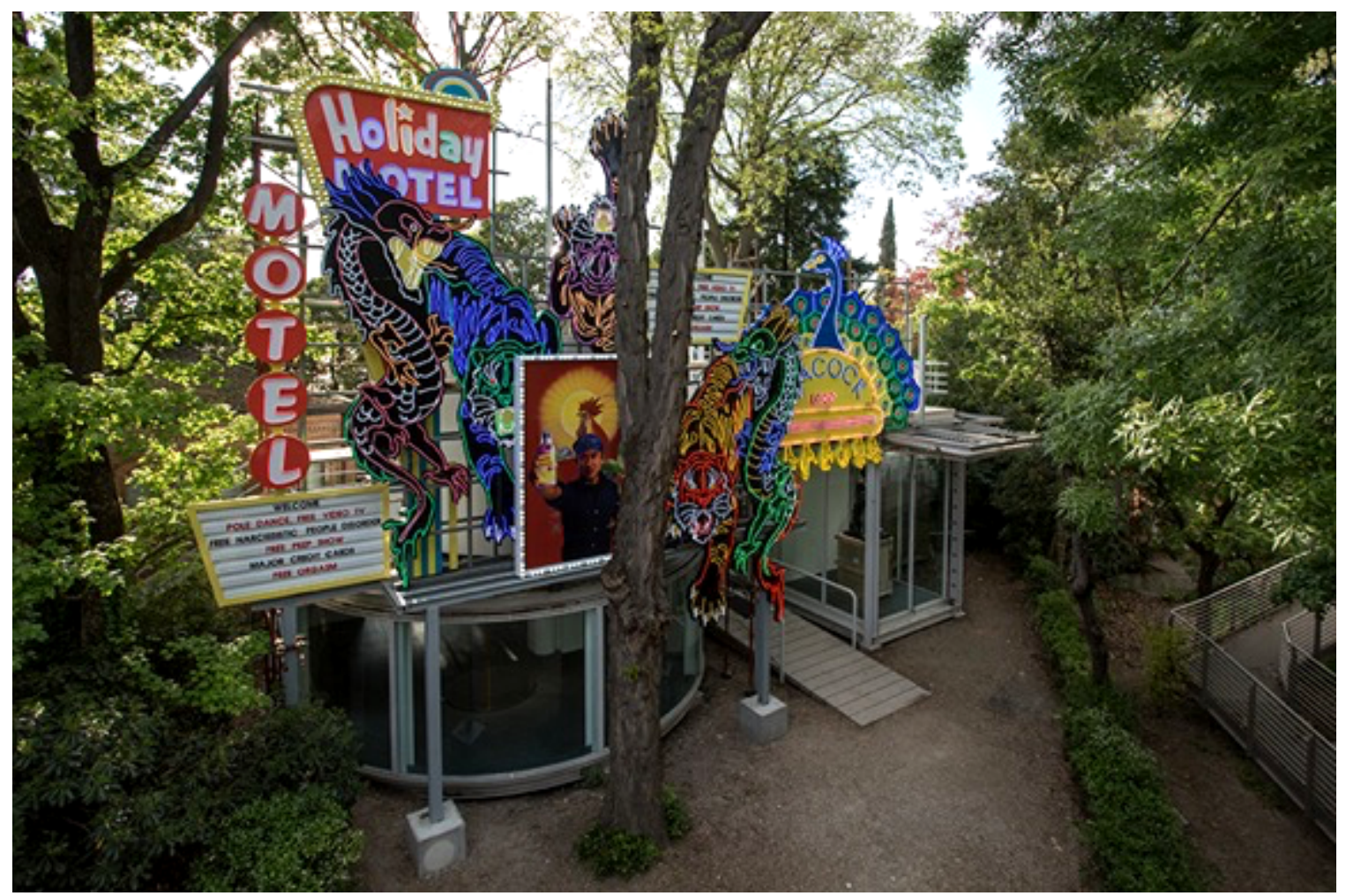

Figure 1. Cody Choi, Venetian Rhapsody - The Power of Bluff, 2016-17. Neon, LED, Steel, Canvas, PVC. Photo by Riccardo Tosetto. Courtesy of the Artist.

Choi's Venetian Rhapsody - The Power of Bluff(2016-17), is a convolution of Las Vegas (literal copy of Holiday Motel of Las Vegas), Myungdong red light district in Seoul, Koreatown around the world, all in one. The installation stages the transnational kitsch that is visually screaming the Korean contemporary life of neon signs and media displays, without holding back any galore. With the predictable exotic motifs of tigers, dragons, and peacock, things fancied by the Western 
audience, the Korean Pavilion entrance shares insight to the glitz of an Asian nation turned Western overnight, untainted by independence of controlled hybridization Korean style, which is not necessarily the Gangnam style exported to the world.

Choi exclaims that the cultural distortion occurs with Korean cultural identity seemingly defined by the West." ${ }^{41}$ His dual monitor double channel National Anthem - Confession of Love for KATUSA and LOVE Affair, 2017, includes the two-folded reality of the American solider singing the Korean national anthem (in Korean) and the Korean soprano singing the American StarSpangled Banner. This interchangeable Korean American influence defines Korea.

The neon tiger especially says it all; some people say that the Pavilion is successful since the Korean tiger is holding fort. The Korean tigers that use to roam the mountains are symbolic, as tigers were the mascot for the Korean 88 Olympics, and as the icon of power and independence, you see historic maps that squeezes in the image of a tiger on top of the shape of the peninsula, which in its shape looks more like a rabbit. During Japanese colonization, Korean liberators were determined to adopt the tiger symbol over the scared rabbit portrayal. The tiger has found the right place to be in Venice.

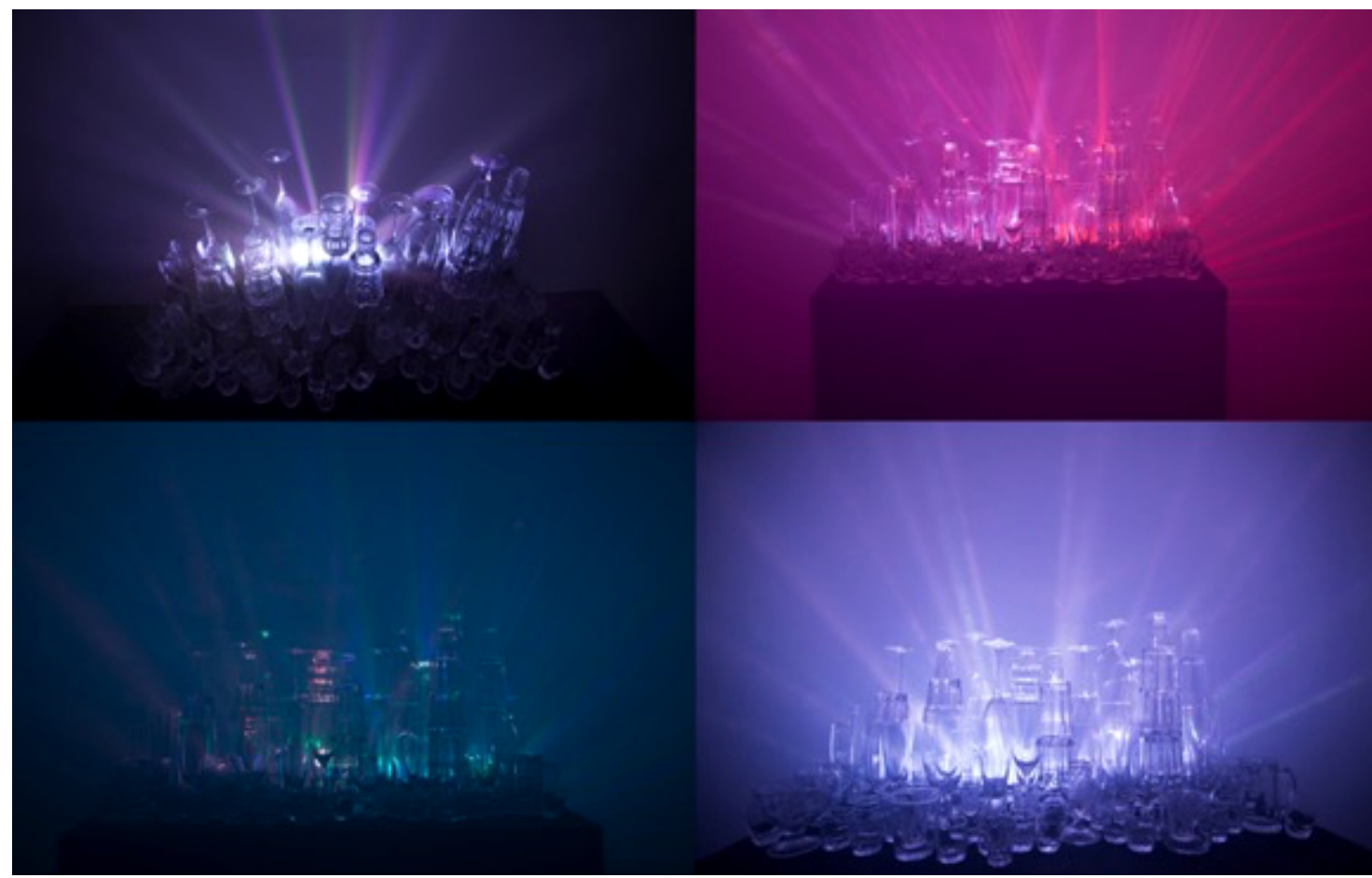

\section{Figure 2. Cody Choi, Color Haze, 2016. Moving light, glasses, fog machine. Dimensions Variable. Photo by Riccardo Tosetto. Courtesy of the Artist.}

According to Lee, Choi was selected for the Korean Pavilion specifically to be the father figure of the transgenerational narrative he was trying to circumscribe with the exhibit. Choi is one of the very first Korean artists who left Korea and went West, lived in California and created his famous piece The Thinker (1995-1998) made by tons of toilet paper roles and the very pink Pepto Bismol. 
The comical story the artist tells is about his indigestion in being in front of beautiful American blond girls for the first time, but his philosophy regarding the digestive disruption caused by the intercultural differences is deeper and something quite else. He was one of the first generations to be out there, although returned to Korea now, but representing Korea in Venice today means he is not going to create charades of traditional and authentic Korea for the Western audience, he is going to be real about sharing the stuff that went down living in the West as a Korean. Choi's philosophy is based on what he calls "cultural indigestion" 42 and I caught him during an onsite interview during the opening with him saying, "you are a Westerner, I'm a Easterner, you are Caucasian, I am Asian, but we all make the same shit.",43

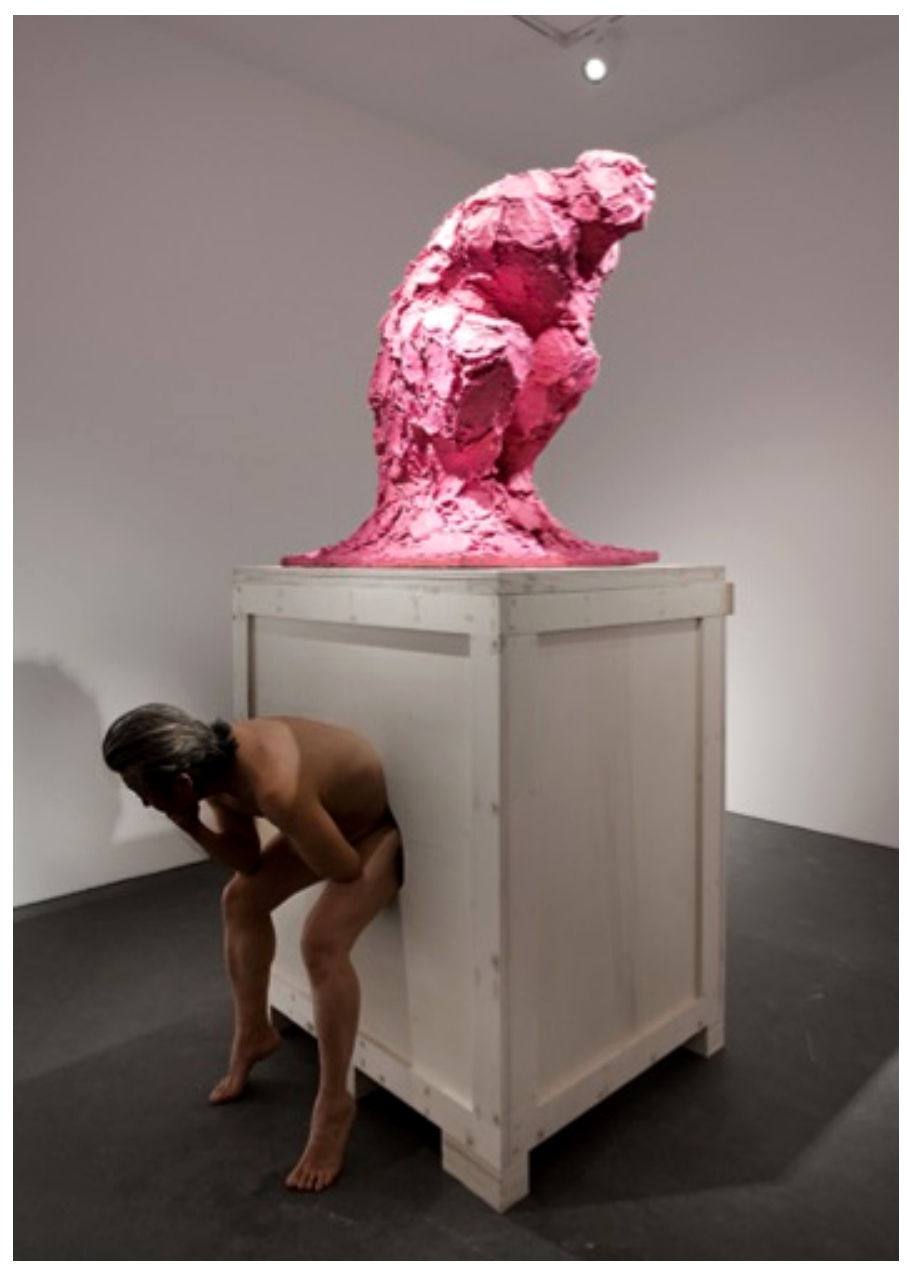

Figure 3. Cody Choi, The Thinker, 1995-96.

Toilet paper, Pepto-Bismol, Wood. Photo by Riccardo Tosetto. Courtesy of ARARIO Museum and the Artist.

Choi's response to his Legend vs Freud's Shit Box (1993-4):

The most shocking of all the cultural classes I witnessed as an immigrant to the Unites States was one concerning physical differences. America's construct of masculinity and 
its macho perspectives, which often belittle Asian men as submissive, feminine and unpleasant subjects, left lasting scars. (Counterbalance, exhibition catalog, 106)

Lisa Lowe in Immigrant Acts addresses the tension in the American Asian identity between the citizen and the immigrant, "as contradictory, confusing, unintelligible elements to be marginalized and returned to their alien origins." "Asia' has been always a complex site on which the manifold anxieties of the U.S. nation-state have been figured: such anxieties have figured Asian countries as exotic, barbaric, and alien" threatening and of as "yellow peril." The racialization of Asians "physically and intellectually different than whites"44 simultaneously existing with the restrictions of the immigration law that come highly pressured during the time the U.S. was in economic and military wars with Asia. The same can be said about racism towards Arabs today, which exists alongside the U.S. foils of war with the Middle East, where refugees signal as both in need of rescue and as an amplified racial and cultural enemy. Choi's work is staged to both combine Korean contemporary narratives and non-narratives into an uncomfortable and humorous turn, somehow engaging all humanities and concerns in one night's affair. The work still however has the underpinning of critique, drawing out necessary and specific cultural nuances of Korea's play in global systems.

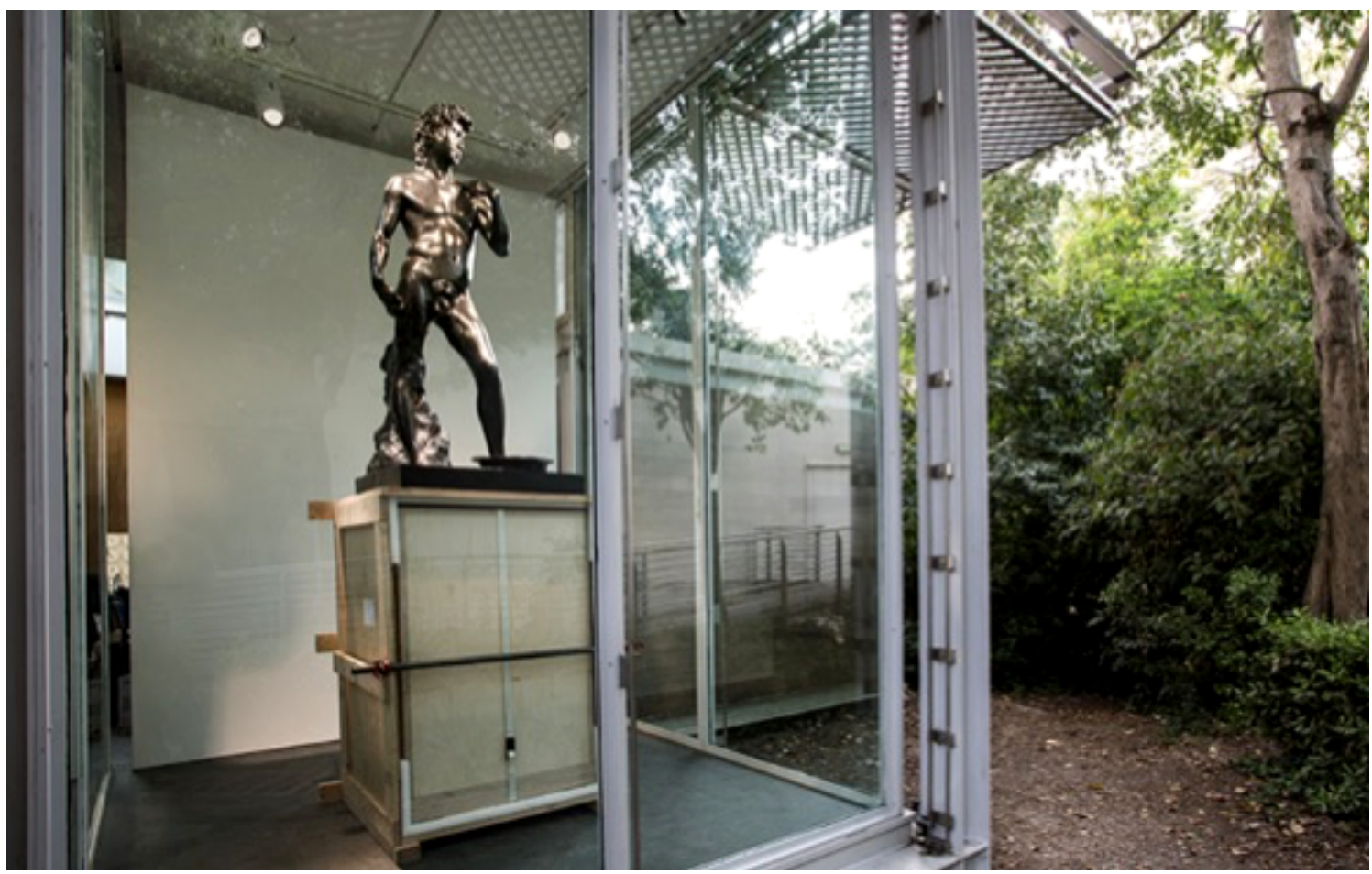

Figure 4. Cody Choi, Cody's Legend vs. Freud's Shit Box, Ed 2/3+AP, 2017. Bronze, wood, steel. Photo by Riccardo Tosetto. Courtesy of the Artist.

On a sober note, Lee Wan, the younger artist who was selected to represent the current rising generation of modern Korea in the scheme of Lee's transgeneration portrayal at the Korean Pavilion, created six pieces including Proper Time (2017) and For a Better Tomorrow (2017), belonging in one installation room. The two works are integrated by a stark formal contrast to 
each other, with over 668 white clocks surrounding the entire walls of the enclosed gallery space with a black family portrait bust sculpture centrally located, placed with awkward sense of stoic monumentality.

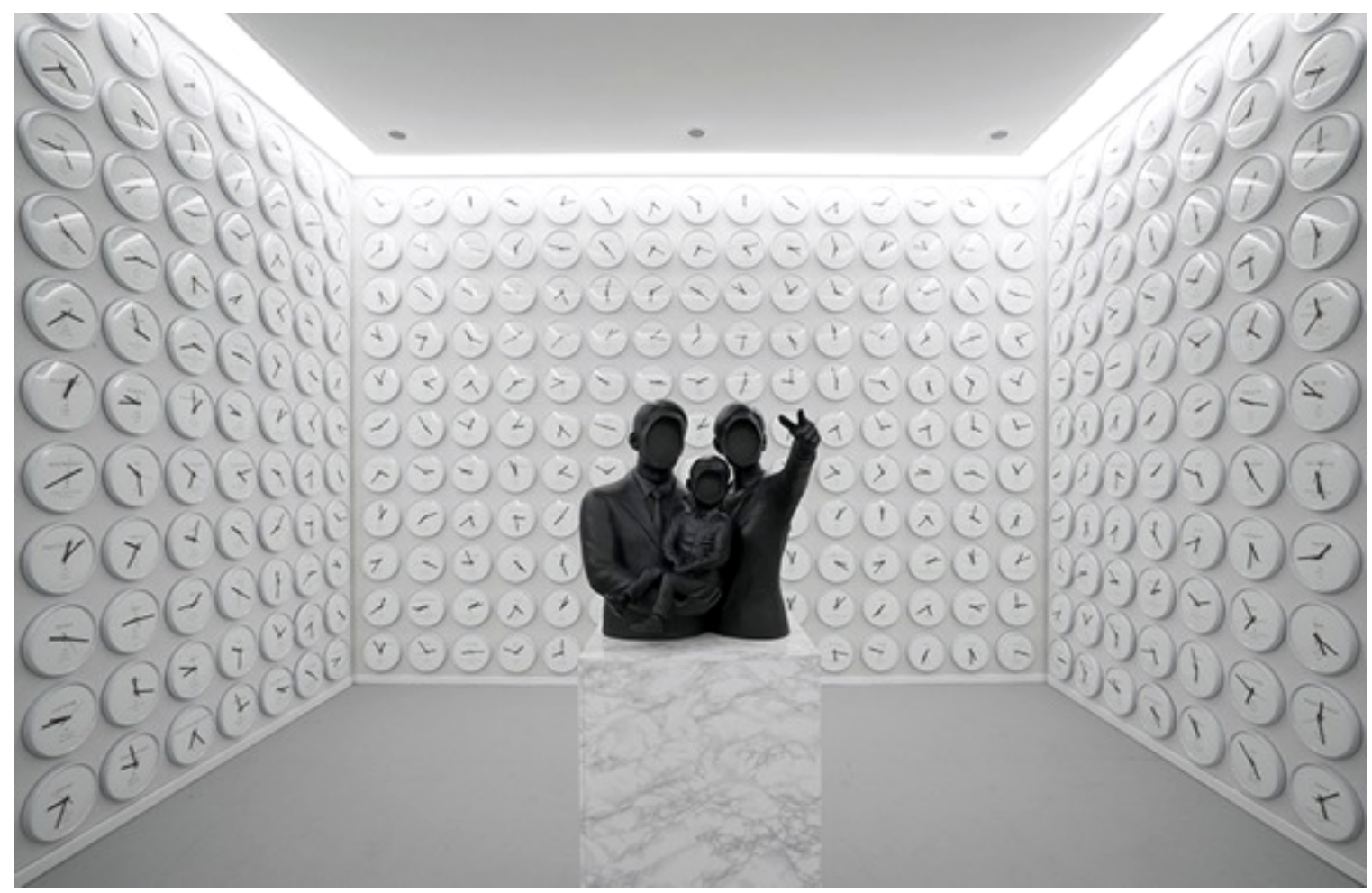

\section{Figure 5. Lee Wan, Proper Time: Though the Dreams Revolve with the Moon, 2017. 668 clocks. Dimensions variable. Photo by the Artist. Courtesy of the Artist.}

Proper Time, responding to Einstein's theory of relativity of time, sets each clock at the pace of the individual's average time working for a single meal, and reflects each person's nationality and economic status. These many clocks then stand in as portraits of the many people the artist directly interviewed from around the world. While the clocks look like generic white IKEA designed clocks, they are all running in different pace of time, with a name inscription of each individual, their birth, nationality, and profession. All the clocks ticking differently create a symphony of multiple "ticking like a time bomb," 45 a surreal sonic space that includes a world's measurement of time in relation to labor, bracketing cultural and personal identity with work hours, economics, and affordability of life.

For a Better Tomorrow is a fake propaganda statue of the ideal family unit of the brave new world; the mother's hand reaches out afar giving direction towards a mighty future. The perfect family of father, mother, and son however has no face, no caricature; they are halo in their future identity or possibly signify change and promise, a difference from their past empty lives. The artist "explores global cultural phenomena influenced by the capitalist system, hybrid or reformed traditions, and individual lives under these irresistible forces." 46 "The figures' faces have been erased; they are no more than placeholders for an idea, 'faceless' being with no character of their 
own - globalized."47 The opening of the duality between the empty and the possibly filled versus the real fakeness of its bronze aesthetic captures the uniquely inauthentic and original Korea, in its very artificial and realistic portrayal.
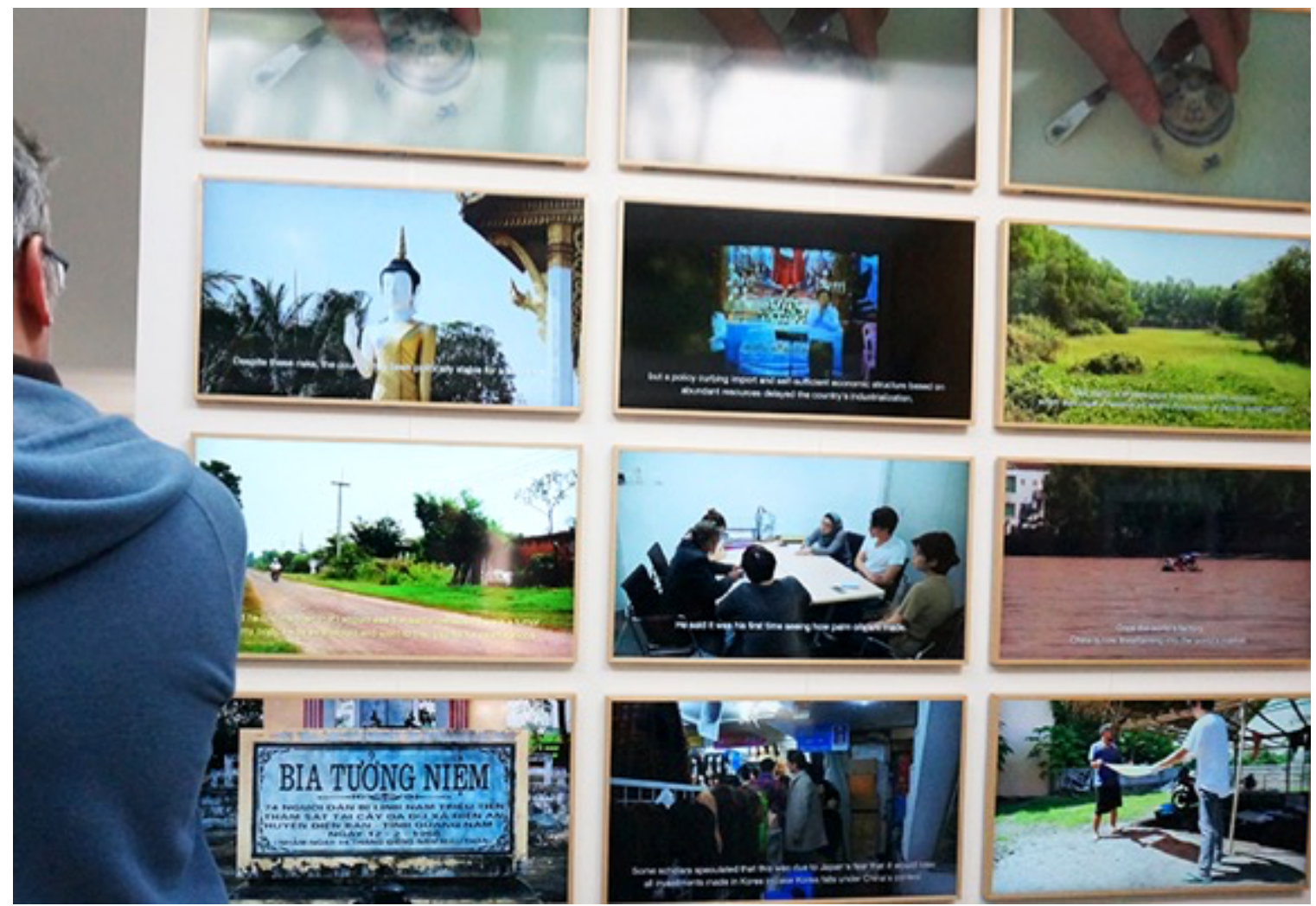

Figure 6. Lee Wan, Made In, 2013-2017.

Multi-channel video, documentation of Sugar made in Taiwan, Coffee in Vietnam, Wooden Table \& Batic Tablecloth in Indonesia, Wooden Dish in Laos, Rubber in Vietnam, Silk in Thailand, Straw Shoes in Korea, Wig in Korea, Palm Oil in Malaysia, Wooden Chopsticks in China, Gold in Myanmar.

Made In, a twelve-channel video installation shows documentations of how one modern person's breakfast is made of ingredients from all over Asia by the hard work of Asian laborers. Lee Wan bears witness to the process of how Asian countries such as Vietnam, Cambodia, China, across ten Asian countries (3 monitors dedicated to Taiwan) have steep labor processes as cultural regiments that are completely neglected in the global consumption of processed food. Retracing back the tenuous labor that supports this consumption culture, as with his other piece Proper Time, Made In, reveals the other story - how things are done, made, produced, and labored, exclaiming one man's privilege is at the cost of another man's life.

Stephanie Rosenthal writes in "Lee Wan_Collisions," 48 that his work for the Korean Pavilion "comes during a period of considerable unrest in this homeland." Korea, as a splintered nation, in cooperative existence on one hand as North and South Koreas, usually amnesiac over being a conflicted war zone unless Western media turns the attention to the Koreas worldwide, has the 
historic record of being a hermit kingdom presiding generations of communist inspired modern totalitarian regime up North and in opposition in the South, as fanatical of conclusive prodemocracy agenda, led by decades of political madness and corruption that includes coups of every kind, ${ }^{49}$ scandals, bribery, impeachments, lock downs, house arrests, imprisonments, and even Presidential suicides (Roh Moo-hyun).

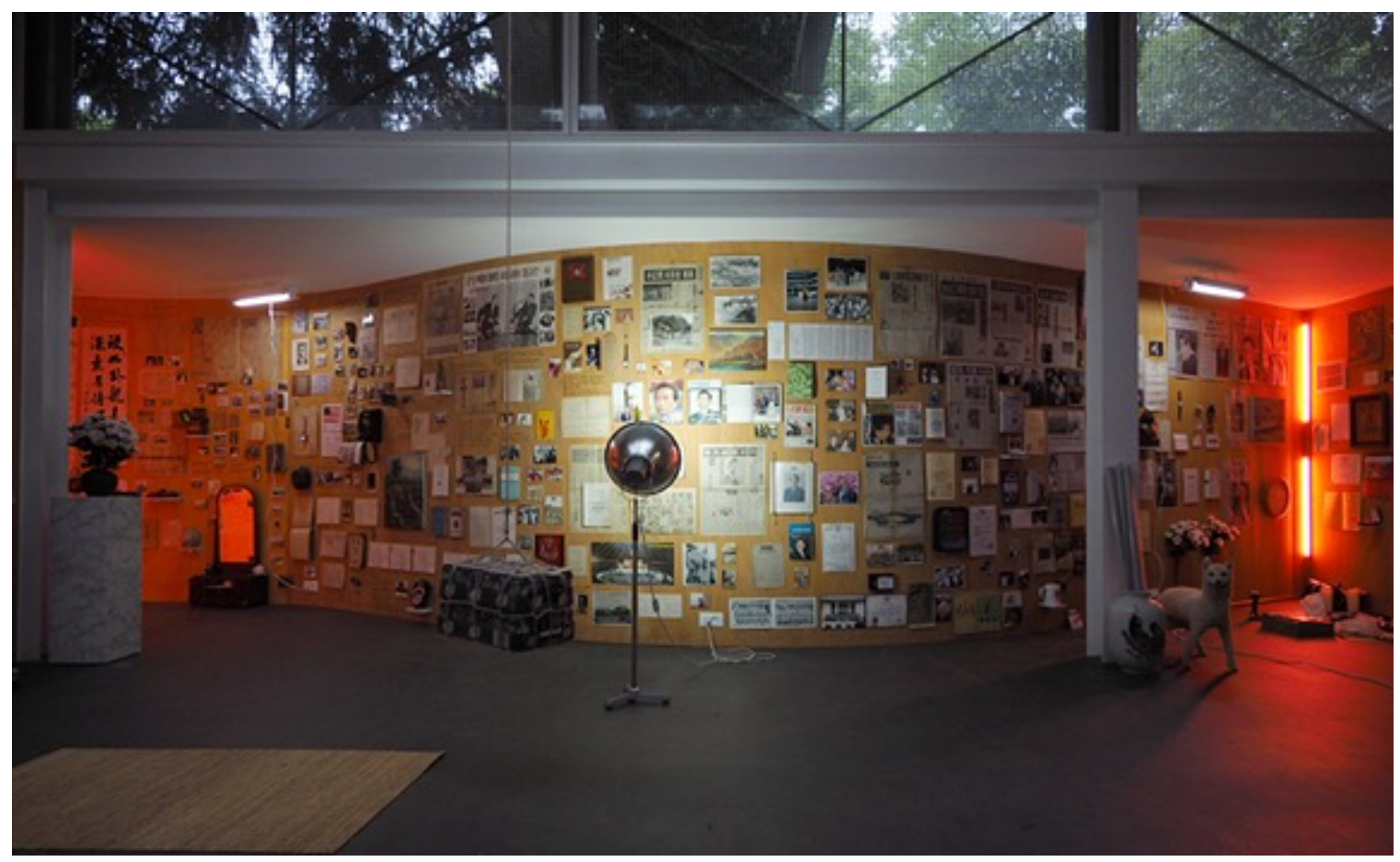

Figure 7. Lee Wan, Mr. $K$ and the Collection of Korean History, 2010-2017. Photographs and assorted archive objects. Dimensions variable. Photo by the Artist. Courtesy of the Artist.

Hence, for the Republic of Korea, Choi is the father figure, Lee Wan is the son figure, and the grandfather figure is a ghost, represented by a series of photographic collection of the life of journalist Mr. K. In fact, Lee Wan bought Mr. K's entire life's collection of 1,412 photos for merely 50,000 Korean Won, equivalent to 50 USD at a Korean antique store. $M r$. $K$ and the Collection of Korean History is a wall of plastered with media prints creating a Korean hall of fame score, that as you enter the Pavilion, the piece takes up the entire right curvature wall, and includes politicians and celebrities in a vast collection of posters, media publication, and objects and memorabilia, and is a floor to ceiling byungpoong backdrop liken to a traditional wall division used for Korean ceremonial offerings for ancestors. The curatorial decision to cast the spirit of Mr. K speaks about bringing out the ephemeral qualities constructed in personal individual histories that can be restructured into contemporary times. The loss of memory for the individual, such as the life of $\mathrm{Mr}$. $\mathrm{K}$, is like the stone, that curator Lee is trying to speak about, is worth remembering and honoring, against the backdrop of the mountain that is the modern nation and the flood of historical information and media expounded to shape its nationalism. ${ }^{50}$ 


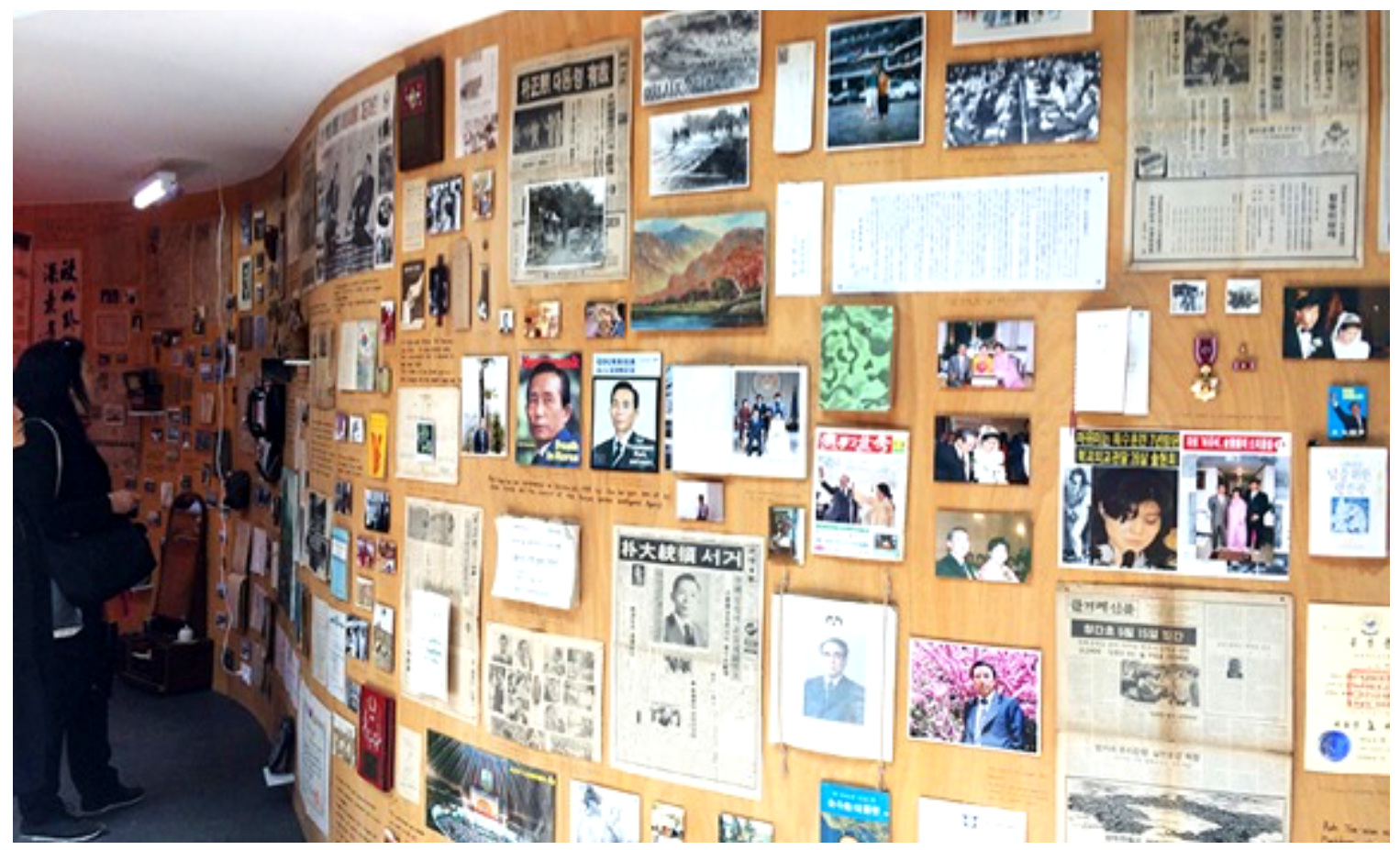

\section{Figure 8. Detail, Mr. K and the Collection of Korean History.}

Lee Wan counterbalances and highlights Mr. K to give light to what constitutes the many ideas and changes of a growing nation towards democracy. The opening the Korean Pavilion immediately followed after the Presidential election results of a human rights activist lawyer, Moon Jae-in as elected new President of the Republic of Korea. It is commendable that Lee as the curator of the Korean Pavilion carefully selected the power male artist combo, between a younger conceptual artist and the older super star artist, to generate a reckless and noisy Pavilion that distracts all the biennale viewers from elsewhere to that way. He also did things differently with intentionality toward clashing cultural moments in order to face up to and deal with the binary world order head-on - to recognize that from big to small, East to West, North to South, these are unnecessary conflations of provisional political and ideological ploys that need to be reconciled.

\section{America Strong, Brave, and Socially Engaged: Mark Bradford Tomorrow is Another Day}

I'm proud to be an American. At least that is how I felt upon entering the U.S. Pavilion in the Venice Biennale 2017 under the dominion of the pavilion's power struck exhibition, and to witness the powerhouse team of the commissioner and co-curator Chris Bedford and artist Mark Bradford $^{51}$ being brave standing strong. Best that this time around, it was Bradford who appeared in Venice and not someone else. I say this not because he is African-American (well that too) but because he is one of the most important artists today who can deliver like no one else, and unhindered by the storms of the world. He is furthermore, unmatched in his parallel social justice work. In comparison to where we are at in the United States, feeling defeated and whip(white)lashed by the politics and daily dread of the next horrifying tweet, most all of us with 
a conscience suffer post-Trump-elected America; seeing Bradford shine at the biennale was a breadth of fresh air. There was a communion of feeling comfort, reassurance, and a sense of promise. Besides being coined the Jackson Pollock" of our time, Bradford "reveals... to be that thing America can use right now: a new Very Important Artist" ${ }^{\prime 53}$ and he as an artist who makes work that is socially engaged, he is an artist who looks to society and "responds with urgency." Artist as citizen, is said repeated while considering Bradford" ${ }^{55}$ and we felt some remedy of making smart America again.

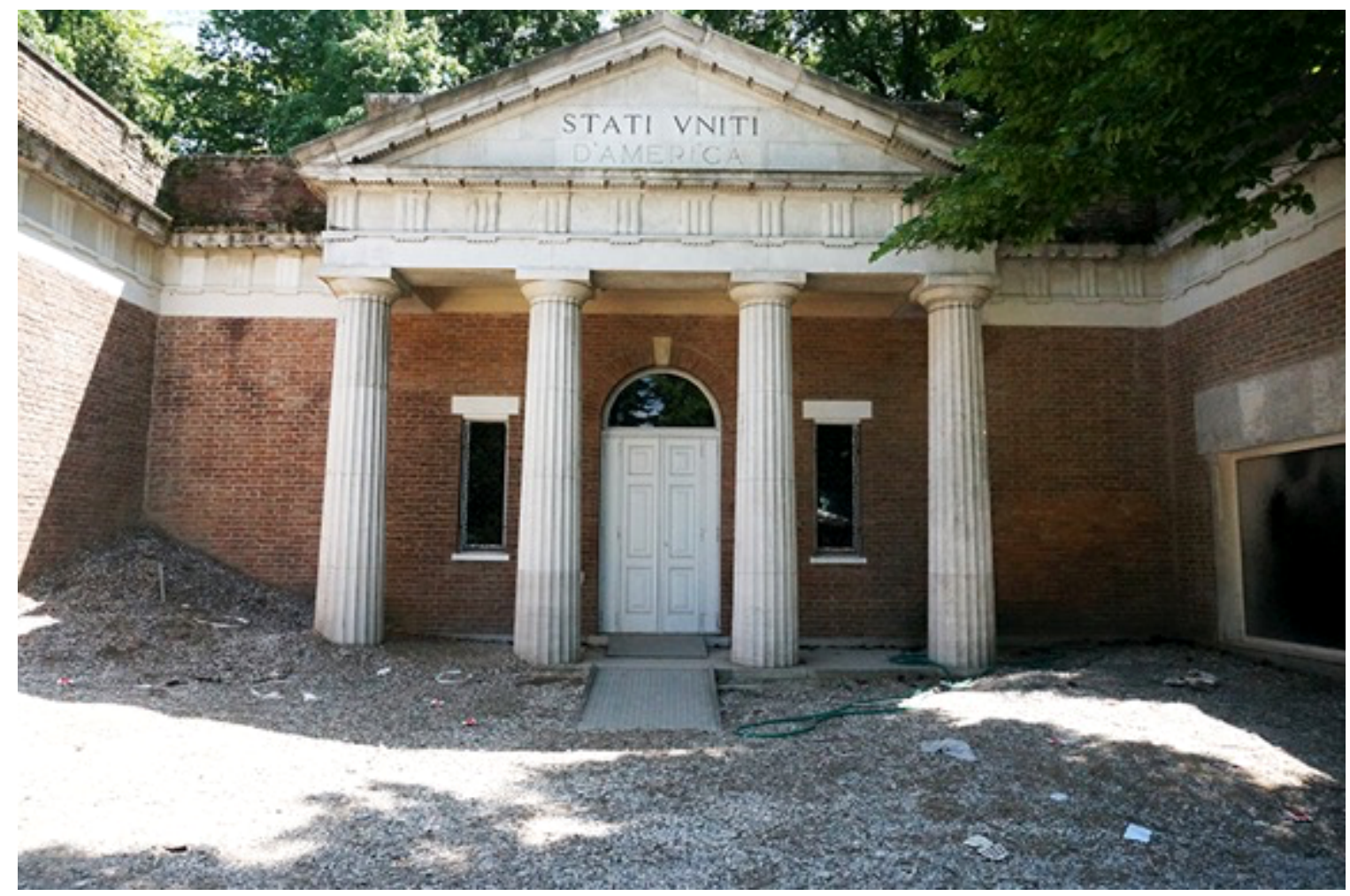

\section{Figure 9. The U.S. Pavilion at the 57th International Art Exhibition, La Biennale di Venezia, was taken over with gravel Mark Bradford scrounged from all around the Biennale site and poured over the pavilion.}

The U.S. Pavilion was taken over with gravel Bradford scrounged from all around the Biennale and poured over the pavilion. In certain areas with more spread of the gravel, no-one knew that was his art covering up parts of the neo-classical pavilion architecture, sometimes referred to as "the White House." People trashed the work with cigarettes and food wrappings, a testimony for blending art and life. The side entrance ("servants' entrance") 56 as the beginning of the exhibition made for a gentle approach to getting inside the White House, setting the audience up with an entirely unexpected beginning with Spoiled Foot, 2016. This mammoth mixed media canvas installation piece draped downwards from the ceiling like an enormous outward belly, taking over the entire room only forcing people to literally move up against the walls to get around the gallery to see the piece. 


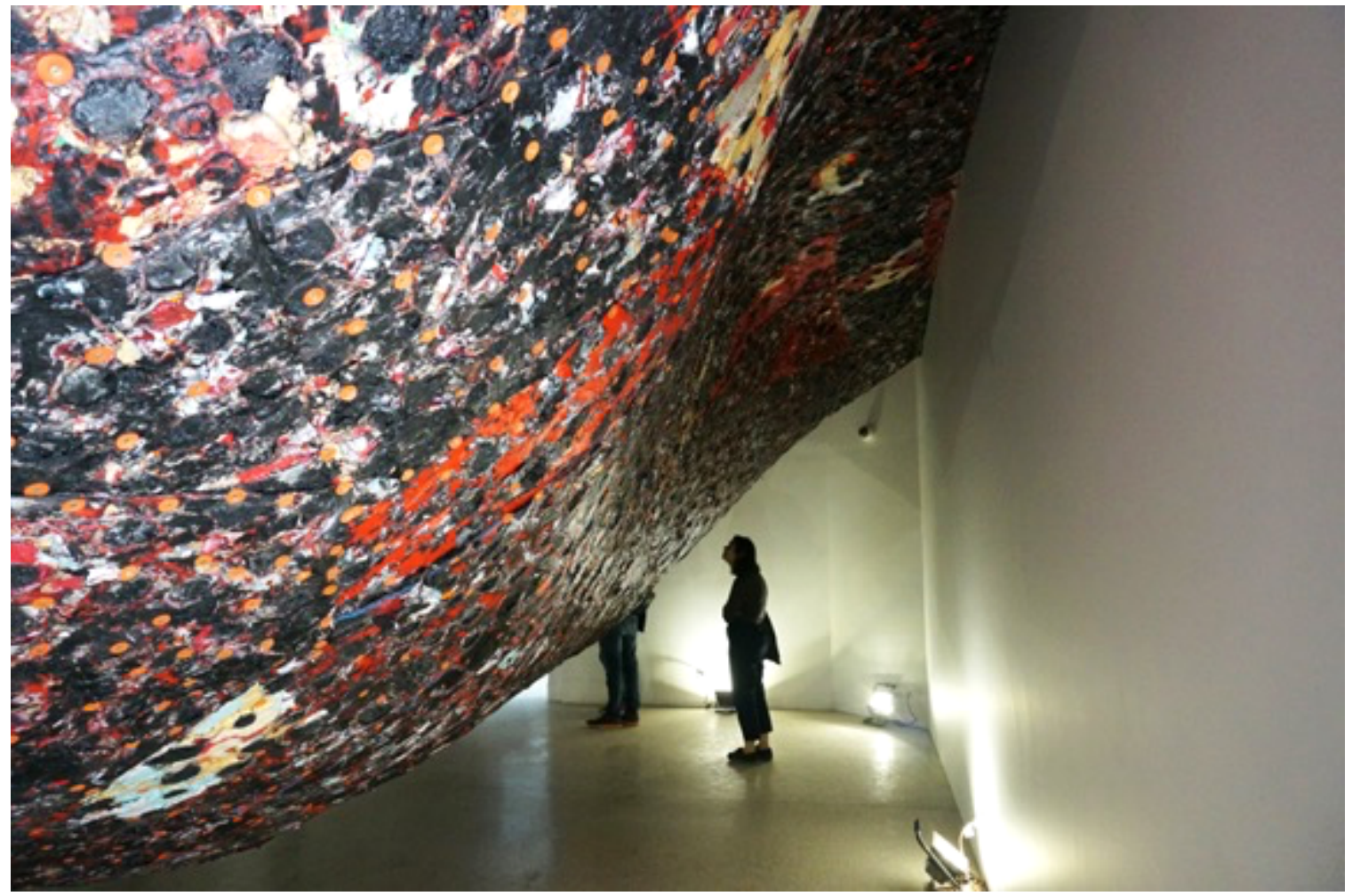

\section{Figure 10. Detail, Spoiled Foot, 2016. Mixed media on canvas, lumber, luan sheeting, and drywall, dimensions variable.}

The piece was heavy to the ground, and the work weighed in on the audience. The very first piece of the pavilion began with great tension between art and life, painting and theatre, and the grit of the work was shocking, as it was a gigantic painting that dropped middle to the ground. Here, we see the collapse of Michael Fried's worst fear, between art and objecthood, as Bradford's art degenerates to theatre and real life. ${ }^{57}$ The exhibition "Tomorrow is Another Day ${ }^{58}$ reveals how individual lives also make history in the greatest sense of the word." "Coming at a moment of terrible uncertainty, Tomorrow is Another Day is a narrative of ruin, violence, agency, and possibility, a personal and historical account of believe in art's capacity to engage us all in urgent and profound conversations, and even action." ${ }^{60}$ 


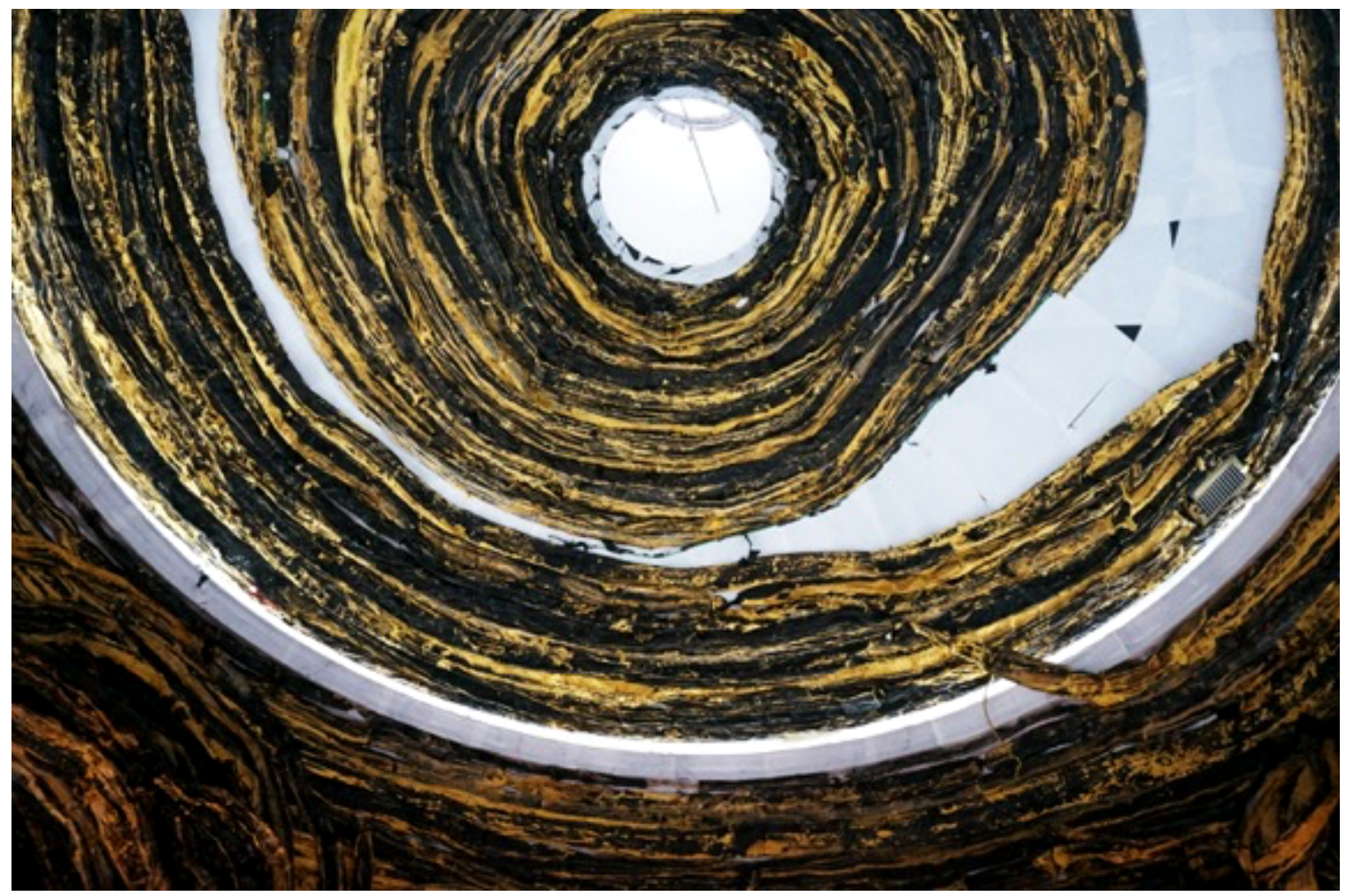

Figure 11. Detail, Saturn Returns, 2013-17. Mixed media on canvas, dimensions variable. Photo: Joshua White. Courtesy of the Artist and Hauser \& Wirth.

The next room of black paintings famously known for being made by hair dyes, Raidne, Theixiepeia, Leucosia (2016), demonstrating Bradford's dedication to the female figures in his life, honored them materialistic but also symbolically as they are the fabric and fiber of his life, his community of support, going back to the time when he worked in the salon. Then, female power in yellow and black is overturned by the ominous Medusa (2016) as a centerpiece to the room, who grows further into the rotunda walls and ceiling, as a site-specific installation, Saturn Returns. By this time, we experience how an abstract painting's foray into cosmology literally caves our experience into the reservoir of the unknown and the unconscious.

Overwhelmed, the next room with mix-media paintings Tomorrow Is Another day and 105194 and Go tell It on the Mountain (2016) helps us gravitate into a calmer universe; on closer look, the physicality and violent markings of canvas that include painting, bleaching, stripping, knifing, returns us to the reveal of urgency and reality of today's social markings that are bravely inscribed in Bradford's work without disguise.

The last room as a video loop takes us further into the social reality, to the streets where Bradford lived, and his filming of a young African-American boy Melvin, who in the film Niagra (2005), walks away slow motion, directly recollecting Marilyn Monroe's scene of a similar shot in 1953's Niagara. Bringing the Venice audience back home to our country where Black Lives Matter, sharing the traumatic history post slavery, civil rights, 9/11 and that we live, as Kirk W. Fuoss 
puts it, where "there is no before-racism in U.S. history. Nor, unfortunately, is there an afterracism." ${ }^{\text {"T1 }}$ The distancing and collapsing of voyeurism in this cinematic moment that has to do with suspensions of disbelief ends the exhibition with a continuous reflective moment that haunts us as we leave.

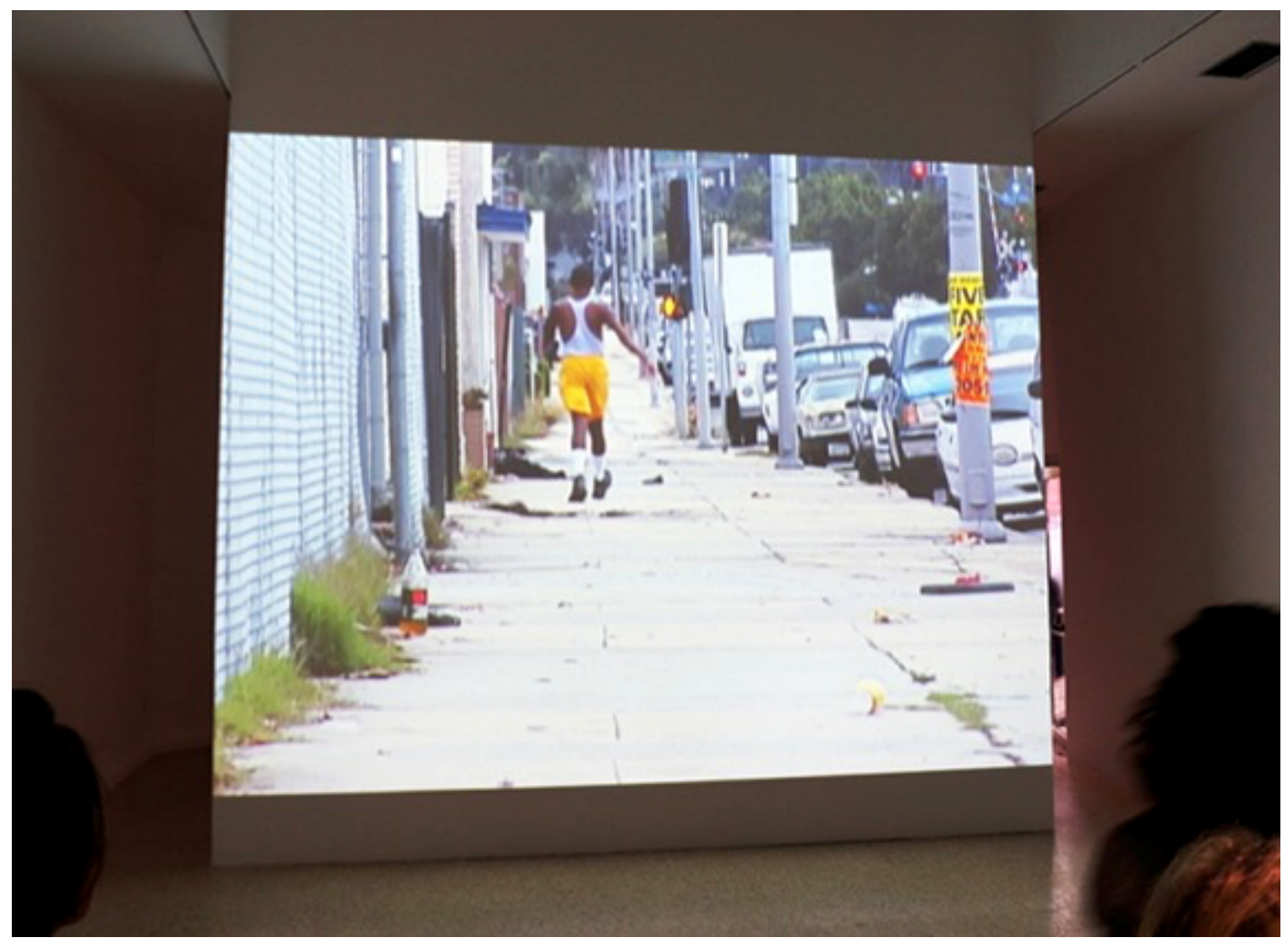

Figure 12. Niagra, 2005. Video, color, no sound, 3:17 minutes, Edition of 5, 2AP.

Just as important as the triumphant exhibition at the U.S. Pavilion, is Bradford's social practice in Venice. Famous for having founded Art + Practice $(\mathrm{A}+\mathrm{P})$ organization with co-founder Eileen Harris Norton and community activist Allan DiCastro, a dedicated program for foster youth to help support those who constitute " $40 \%$ of the local high schools' population" in south Los Angeles "by offering life-skills training, access to housing opportunities, support for education and employment, and individualized case management."62

During my interview with Bradford about refugees, he responded to the concerns of lack of lasting support and resolution worldwide for them. He talked specifically about the ability to work in manageable scales when working on socially engaged art, such as his project to help prisoners Process Collettivo, a six-year effort. As a collaboration between Bradford and Rio Terà dei Pensieri (RTdP), ${ }^{63}$ a nonprofit social cooperative, this work demonstrates how to mobilize real support that is lasting. The problems with the refugee crisis are that, the program and support is temporary at best, and countries need to help support not only the admittance but also the 
assimilation and adaptation process into the new country, and with full responsibility towards regaining one's rights. ${ }^{64}$

During the time of preparing for the biennale exhibition, Bradford's dedicated work with prisoners in Venice integrated his "knowledge and keen sensitivity with respect to the issues of hardship and social redemption [that] led him to give life to Process Collettiv." ${ }^{65}$ Out of this, they created products with the brand name "Malefatte" meaning "wrong made or misdeeds" from the Silkscreen Lab and the Bag Manufacturing Lab. Also from the Produce Garden, and Cosmetic Lab, everything from bags, accessories, t-shirts, organic fruits, and beauty products, gave prisoners opportunities to work and sell product outside the prison. The proceeds from the sales go back to supporting the existing programs as well as new projects for providing work to the inmates, which is about giving them agency and a greater range of support for rehabilitation back to life. ${ }^{67}$ The reason as to why the "prison-based economy" helps society is spelled out in four determinate factors: jobs help inmates away from repeated offenses, currently only 2,000 of 60,000 prisoners are employed, prison economy can help national growth, and the products coming out of the prison are of excellent local manufacturing. ${ }^{68}$

Prison work today has become a widespread reality that has spread to almost every region of Italy. The belief that even while incarcerated you can gain quality work experience, offering people in reclusion the opportunity to have small pockets of freedom, exchange, and satisfaction, has become one that many people hold as important. As a nonprofit, RTdP is contributing to this cultural change. Mark Bradford has planned to collaborate with RTdP for six years, with the aim of increasing employment and training opportunities within the prisons and the city of Venice. (RTdP, 40)

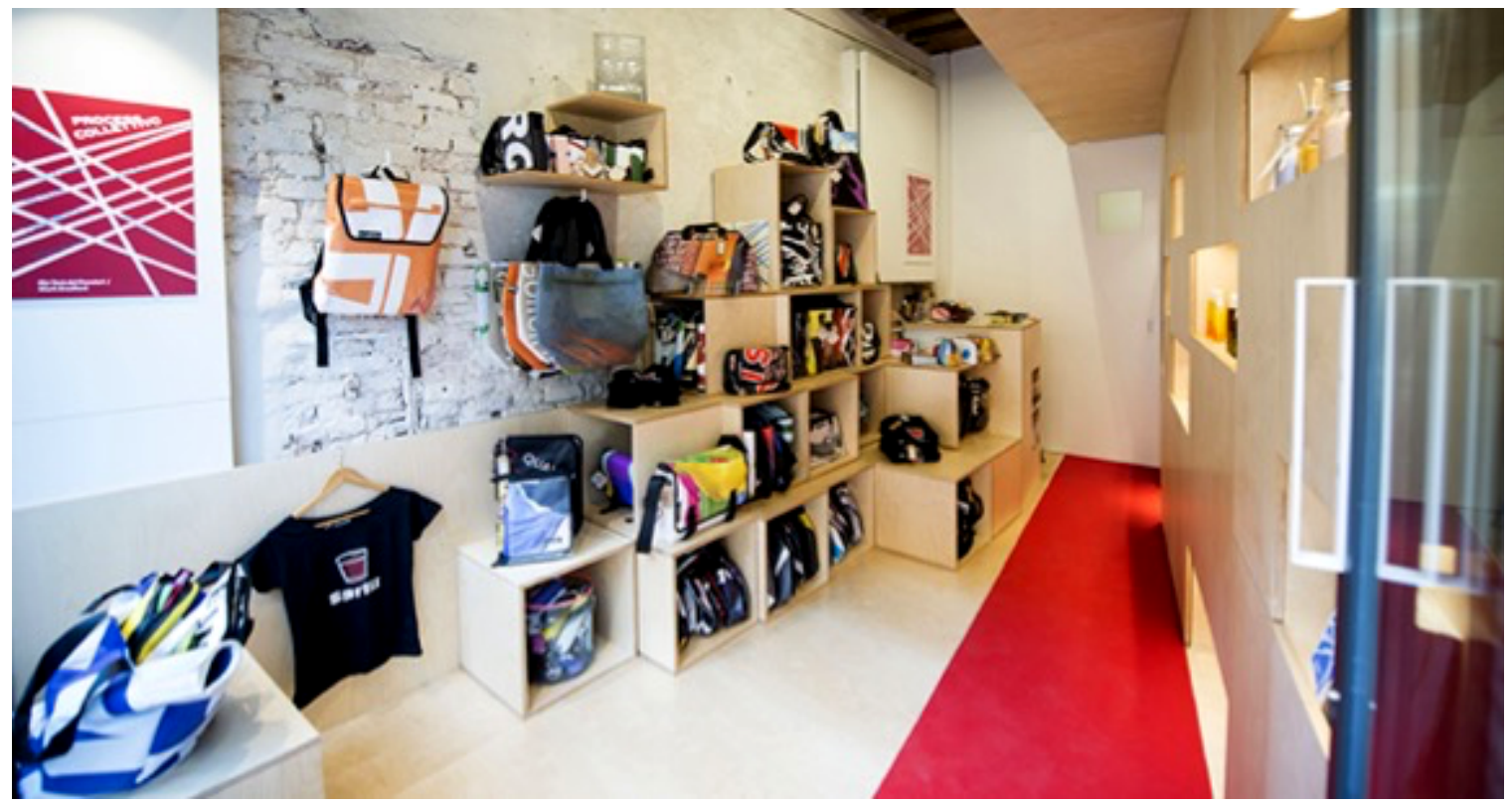

Figure 13. Interior view, Process Collettivo, San Polo 2559a, Venice, Italy. Photo: Joshua White. Courtesy of the Artist and Hauser \& Wirth. 
Of all the literary criticism that rose in response to the prison system, the famous Foucauldian panopticism $^{69}$ shed light on how the fear of authority through imagined surveillance in prison system helps control prisoners and shape behaviors, and how the same internal system of control can be used to monitor and produce docile bodies in the external and highly surveillance society. Although a bit of a background noise, theories on structures and power gives some space of thought about how to digest the prison system and its relation to the outside world, as well as the construction of identity whether in prison or in real life. More recently, Angela Y. Davis in Abolition Democracy: Beyond Empire, Prisons, and Torture ${ }^{70}$ writes about the need to question the authority of law itself, as we lean on the law to sort out justices, it is under the same law that injustices exudes. Davis points out:

Perhaps the lesson in all of this is that we need to find ways of contesting the absolute authority of law. We might phrase the following question: How do we use the law as a vehicle of progressive change, while simultaneously emphasizing the importance of acknowledging the limits of the law - the limits of the national law as well as international. For example, we naturally assume that justice and equality are necessarily produced through the law. But the law cannot on its own create justice and equality. Here in the U.S., thirty years after the passage of what was considered unprecedented civil rights legislation, we are still plagued with many of the same problems of inequality relation to economics, race, and gender. (Davis, 93)

The law does not care about the conditions that lead some communities along a trajectory that makes prison inevitable. Even though each individual has the right to due process, what is called the blindness of justice enables underlying racism and class bias to resolve the question of who gets to go to prison and who does not. (94)

Davis' recounts how the failure of "prison-industrial-complex' is related to the failure of abolition democracy (DuBois), that itself exists with the failure of abolition of slavery, death penalty, and prison. These are other legal mechanisms to keep and maintain "new institutions [created] to incorporate black people onto the social order." 71 On a global scale Davis further comments, "Human rights instruments can be strategic tools in the struggle for global justice. But we cannot ignore larger processes, such as the movement of global capital, which assaults entire populations. Campaigns to defend the rights of immigrants in post-colonial urban centers in Europe and the U.S. must insist on the human rights of African, Latin American, Asian, and Arab immigrants." 72

What citizenship means for the immigrant status or similarly, regaining agency when a person can leave the prison returning back to society, is about the ability to have access to life resources as well as the support to rehabilitate. Bradford's social engagement work with prisoners helps us think about the direct support that can further help refugees as well, or how to create programs that can sustain further integration of immigrant lives.

Moreover, in thinking broader about Bradford's social activism, Pablo Helguera's Education for Socially Engaged Art comes to mind. The book is an important source in the education of social practice and defines the possibilities in the community and the role of the artist to go beyond just making art. Social practice as the new academic term for socially engaged art "excludes, for the first time, an explicit reference to art-making... ... The exclusion of 'art' coincides with a growing general discomfort with the connotations of the term... Instead the term democratizes 
the construct, making the artist in to an individual whose specialty includes working with society in a professional capacity.",73

Existing between symbolic and practical social engagement and exercise, Helguera defines Socially Engaged Art (SEA) as:

Social interaction occupies a central and inextricable part of any socially engaged artwork. SEA is a hybrid, multi-disciplinary activity that exits somewhere between art and on-art, and its state may be permanently unresolved. SEA depends on actual - not imagined or hypothetical - social action. (Helguera, 8)

Bradford's social practice invests in understanding the "need" of the community and providing real "access" to complement the need as the parameters of his constructive social action. "Need' represents Bradford's attention to the specific nature of different marginalized populations in order to identity and help them fulfill their essential needs, which might include employment, education, housing, and health." "75 From practical life needs to skills to operate and build life in society by creating opportunities of "access" which as a tool "gives the selected population exposure to ideas not typically encountered in their daily experience... opens a new world to them... mobilizes hands-on, invested interested, such as Bradford's, as a means to raise awareness of and shift perceptions" of those outside society, prisoners and foster youths, "making visible the invisible, supported by pragmatic initiatives, is key to access."

In Venice, for Bradford to work with RTdP for a lengthy period with SEA programming engages prisoners and gives them real opportunities to succeed when in prison and helps their success continue as they go out. The support for reintegration into society related to job training probably helps make their time more bearable, and also helps guide them for thinking about a future. This humanitarian level support for prisoners, facilitating how they can empower themselves with the right program or support system, is an important step in figuring out how art and activism can work in tandem in the most effective and meaningful way. Here, we don't separate the project from the work, from the art and the socially engaged, the artist and the community. Bradford states:

It has always been important to me that art not exist in a vacuum. Art must engage with society; otherwise, what is the point. I have always learned from my experiences that one of the best ways to engage with a population is the connect locally with the surrounding community. (RTdP, 9)

During the U.S. Pavilion opening, I had the opportunity to interview a prisoner who was let out just for the opening days who worked with Bradford on the Process Collettivo project. His temporarily given name is "Pietro" "77 and he shared his screened and sewn bag that he created in prison. Showing his merchandise product, he was thrilled to be at the Pavilion. Just by the mere fact that an "artist" from the prison was able to have his opening with Bradford at the Venice Biennale shows the love and care and the devotion of the project from the entire community and the spirit that carried the day surrounding the Bradford's boundless generosity and creativity. The next day, upon entering the Process Collettivo Store in the middle of Venice, the chic store that housed hip urban bags and products was packed. Indeed Bradford's "financial and proactive commitment to RTdP have made it possible to open a unique retail store and resource center to 
the public, which brings with it the story of the people who have worked and produced unique creations, as well as their troubled pasts, present responsibilities and future aspirations."78

What seems like today's global political downfall, was already addressed a decade ago by Amy Goodman and David Goodman who introduces their book in Standing Up to the Madness, with startling sentence that "When fascism comes to America it will be wrapped in the American flag." America great again as the new patriotism and nationalistic ideology rise. Immediately after the elections in the U.S. you see Fischl's painting "fresh off the easel" ${ }^{80}$ showing the vulnerability of the older father figure laying naked bare at the edge of the pool with the future rise of American patriotism signaled by a boy draped in the American flag hovering over, lighting a backward vision of our future as its come. The solution, "How to Stand up to the Madness" starts with a "single act of resistance." 81 The Goodmans laid it out for us years ago - we just need to pay attention in that, resistance is to: challenge the corporate media (stop big media, support independent media, create your own media), not follow the leaders (stop torture), question authority (bring the troops back home), speak up, defend your rights, confront racism, fight censorship. We must "defend our liberties. Speak truth to power. Fight for those who can't."

Helguera eloquently spells out the difference between social work and social practice, that there is a difference ${ }^{83}$ insofar that there is an accountable artist involved, creating education, and space of reflection, assessment, evaluation, and social action. In this case, and in the case of Bradford as example, "the artist is a teacher, leader, artistic director, boss, instigator, and benefactor, and these roles must be assumed fully" ${ }^{\prime \prime 4}$ and that is why Bradford is citizen and artist, and this makes for the backbones as to why his paintings matter more over time. Where art and non-art meet, "just doing" is the performance of "single act of resistance" today. ${ }^{85}$ Bradford's paintings and social practice together as a true multi-disciplinary activity is in Allan Kaprow's way of "paying attention to the normally unnoticed [and] what is conventionally hidden" ${ }^{86}$ and bringing them out in the most noticeably profound and impactful ways. We are seeing a new paradigm of unapologetic abstraction and action at work.

\section{No-Man's Land, Supranational Brand, Nation as Imagined Art Land: The Antarctic Pavilion and Biennale}

The Antarctic Biennale is an impossible project - to go to Antarctica to create art temporarily for no one (accept for maybe whales and penguins, and the artists themselves), document what is possible and bring it back to the Venice Biennale for an international viewing of the expedition as a "documentation" exhibition at the Antarctic Pavilion. Hoping that the art audience can feel and examine the exhibition that shares glimpse and highlights, the experience of being at the site of no-man's land is a great attempt. Yet without the ecological danger, severe climate, and mother nature taking over the helm as the artists and voyagers so kindly explained, there were no words to describe the feelings of the constant motion of the boat and the adventures out on the lands getting to Antarctica. The expedition experience cannot be encapsulated in an exhibition format as I hear, but provides an insight about the experience far exceeding anything beyond what can be mounted or imagined. 


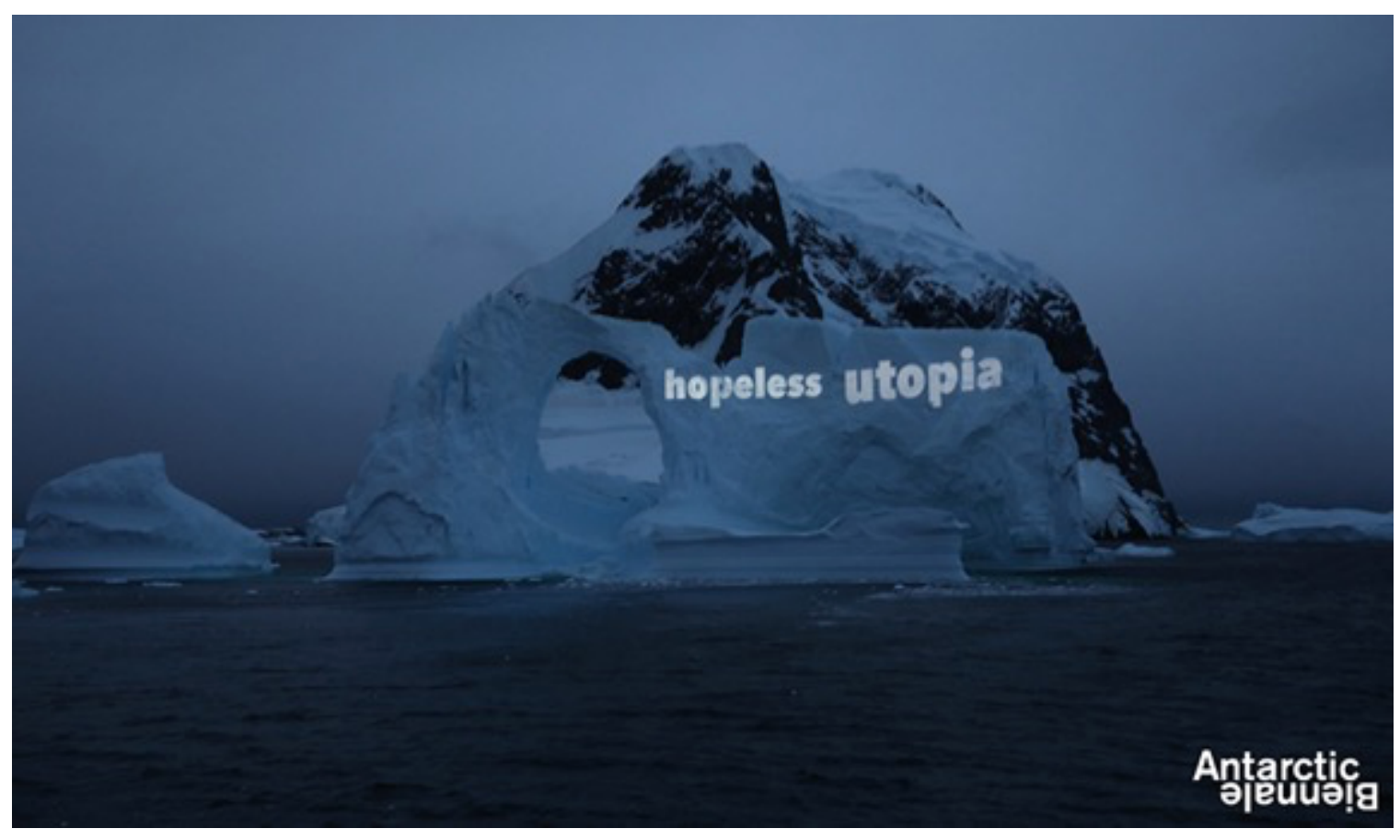

\section{Figure 14. Alexis Anastasiou (Brazil), It's Cold out There, 2017. Large-scale projection. Photo courtesy of the Artist and the Antarctic Biennale.}

A key philosophy to this voyage is landing on "shared spaces" (such as Antarctica, the Ocean, and the Cosmos), ${ }^{87}$ the continent is a "supranational" ${ }^{88}$ union, under the 1959 Antarctic Treaty ${ }^{89}$ that includes The Protocol on Environmental Protection to the Antarctic Treaty signed in $1991^{90}$ for sustaining environmental preservation and shared now by 53 nations. Since the co-signing of the original twelve countries, more stations with researchers and scientists have docked their territories on fertile grounds for the sake of stocking up on research and global peace. ${ }^{91}$

These stations over decades have created their own micro-community hubs, small pockets of their individuality and nationality, disguised over the massive snow of anti-national claim and sovereignty called Antarctica. In turn, the art biennale as practiced on and off the boat with temporary installations, performances, and exhibitions done on specific sites and left nothing behind, had international artists make their silent marks on the Antarctic scene, thwarting "art for art's sake" at the forefront over all other agendas.

As avant-garde as the charge is to lead a group of artists to such heightened geopolitical space that is erased in politicality through the massive bleak whiteness, stopping the clock for an art moment in the timeline of earthly anthropocene epoch ${ }^{92}$ is radical, poetic, and dangerous for mankind. The supranational brand and creation of the Antarctic as art land goes with the massive launch of art first, over science, as a new means of global navigation for the future. Whereas art is the new promise for the future, progressive modes of futurity that propelled modernism and modern art, and this snow project invested in art as globality and futurity, is as exciting as it is in all its grandeur promises and ubiquitously utopic. 


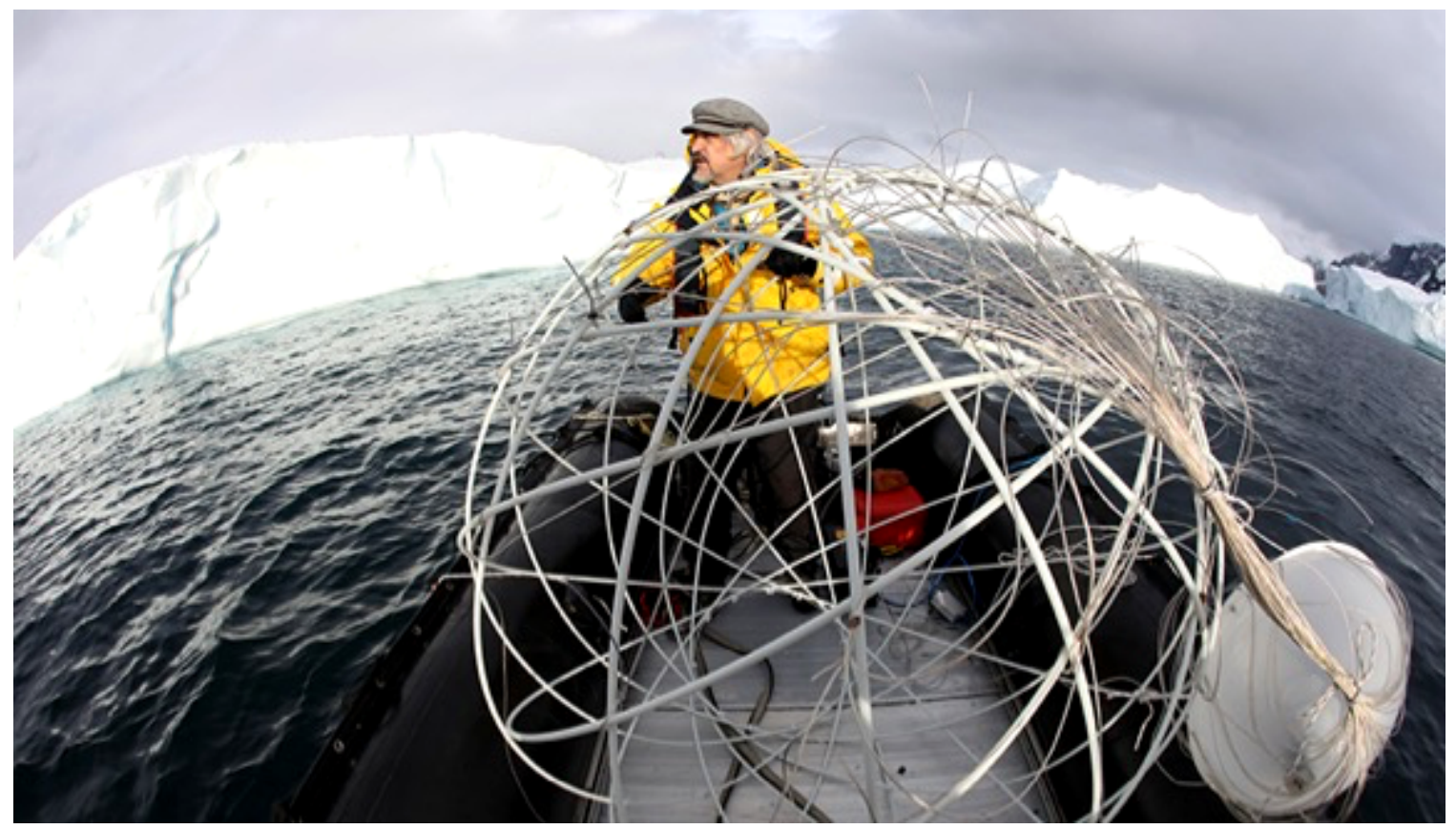

Figure 15. Alexander Ponomarev (Russia), Alchemy of Antarctic Albedo (Or Washing Pale Moons), 2017. Underwater installations. Photo courtesy of the Artist and the Antarctic Biennale.

Social media helps expand our virtual presence via shared spaces; the expedition is then no different than an extension of man and media, to go boldly where no one has gone, the uncharted territories and the final frontier on earth, the next stop can only be none other than outer space. Man's reach is only limited by imagination, certainly not by technology, as witnessed by the Antarctic Biennale.

The mastermind behind this bold operation is a man with wild visions, infamous Russian artist and seaman, Alexander Ponmarev, who makes art happen "on the edge, ${ }^{, 93}$ leading his A-list culture team of artists, architects, writers, researchers, scientists, documentarians, and curator Nadim Samman, who co-curated the Antarctic Biennale centered on the expedition project with Ponmarev. Checking out from reality (and the Gregorian calendar) as a crew, the culture pack leaves behind daily comforts into the vestige of an inhabitable world. While this self-curated displacement from time and world order seems extreme, artist Julius von Bismarck saliently puts it, "it was about being placed, rather than displaced." 94

Our project has among its goals a search for purity, openness and silence! Every artist is aware that both the end and the beginning depend on the point of view. Antarctica is a sort of zero point of the Earth's axis, around which the world rotates. The closed nature and perfection of Zero presupposes a range of new possibilities. (Alexander Ponomarev, The 1st Antarctic Biennale, 15-16) ${ }^{95}$

Heading out March 17, 2017, under the patronage of UNESCO, the $1^{\text {st }}$ Antarctic Biennale left Argentine port Ushuaia on a scientific research vessel 117-meter-long ship known as the 
Akademic Sergei Vavilov to Antarctic Circle; the crew returned to Buenos Aires on March 28. The image of the trip being a brutal expedition that includes each man's physical exhaustion is undermined when seeing images of the posh and magnificent love boat. But the exertion was real with the ship traveling " 2,000 nautical miles $(4,000 \mathrm{~km})$, making over 12 landings on the shore of the Antarctic peninsula and on islands," and while carrying out over 20 art projects that demonstrated both artistic value and "strict observation of the ecological requirements of a human activity in Antarctica." 96

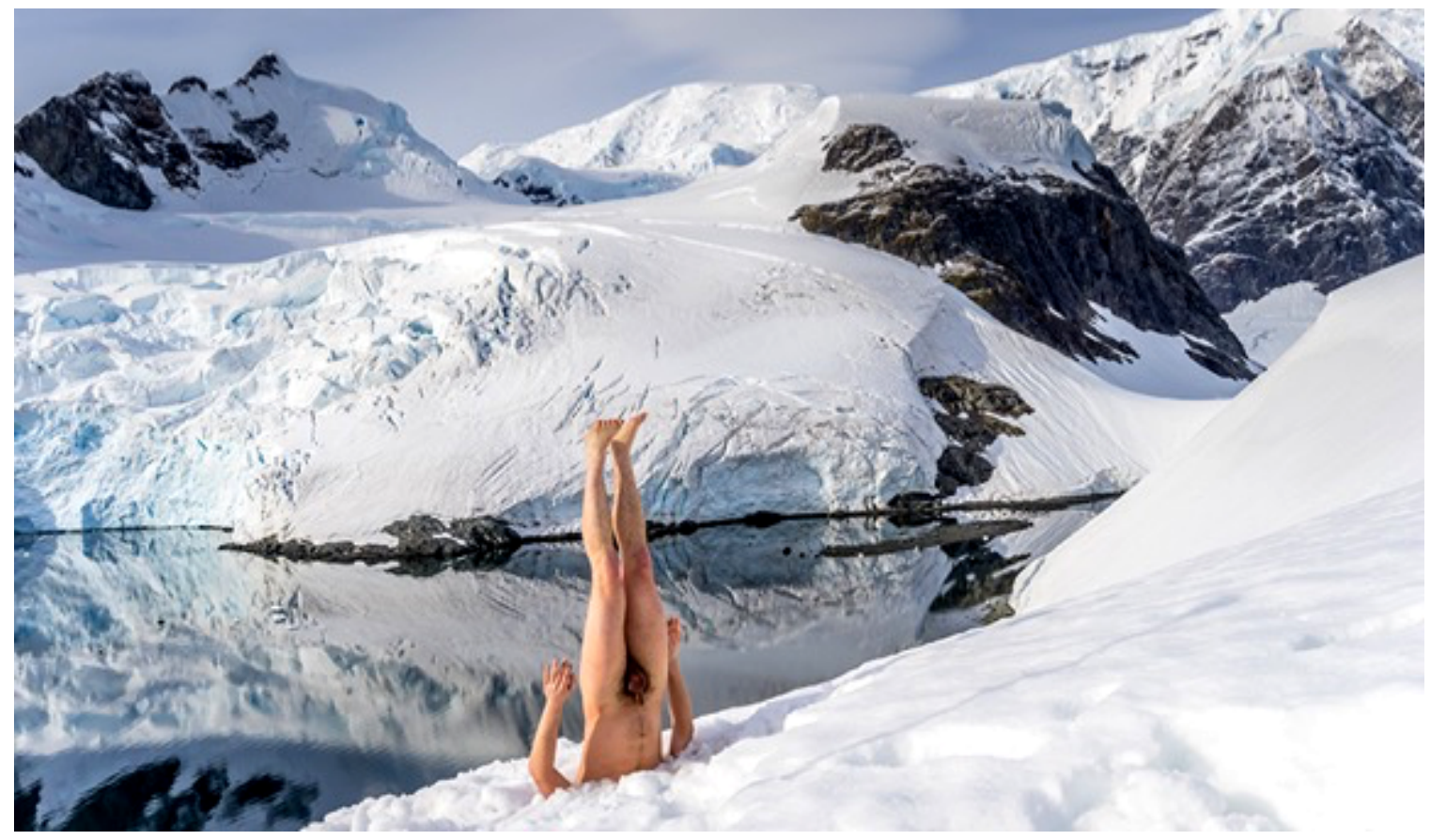

Figure 16. Andrey Kuzkin (Russia), The Phenomenon of Nature or 99 Landscapes with a Tree, 2017. Series of performances. Photo courtesy of the Artist and the Antarctic Biennale.

A singular curatorial vision was shaped by Samman, "What potential does the Antarctic Imaginary hold' - for exiting polarized identity politics, and ecological insensitivity in public culture" 97 and the biennale focused on providing artistic "series of newly commissioned works exploring the aesthetic, conceptual, and mythic parameters of the Antarctic Imaginary."98 For defining such parameters, the project is mammoth in program, voyage, and exhibition. ${ }^{99}$ Starting with the formation of the Antarctic Biennale Vision Club in different cities around the world, international open call for young artists participants with jurors and with an esteemed artistic advisory board that included Ponomarev, Samman, director of Sharjah Art Foundation Sheikha Hoor al-Qasimi, art critic and curator Hans-Ulrich Obrist, director of Fondation Beyeler Sam Keller, and co-founder of Asymptote Architecture Hani Rashid.

The voyage included a "lecture read to the penguins"100 actions, happenings, not-happenings, ${ }^{101}$ performances, site specific installations, temporary exhibitions. While the travelers "on the same ship" communed together the many stops wayward South, art within the boat acted as a "floating studio" that included an onboard program ${ }^{102}$ with labs, symposia, and film screening. Cultured 
bodies integrated on the way to edge of the earth, cultivating their own protective layer of second skin of cultural intelligence amidst the turbulent ride and challenges of the frozen environment. The long voyage included Ushuaia, Drake Passage, Neko, Paradise and Orne Harbours, Cuverville Island, the Errera Channel, the Lemaire Channel, Pleneau Island, Petermann Island, Penola Strait, South Shetland Islands, to "Deception Island," "Half Moon Island," Yankee Harbour (!?) and Cape Horn. Each landing and visit to a scientific station moving towards the South seems more fantastical. Especially curious are Deception Island and beyond, similar to the nuclear testing grounds of Bikini Atoll; strange communities are formed in such research stations. Many reviews relate to the grand gesture of voyage itself, ${ }^{103}$ but the places visited on the way as well as Antarctica as a contested space are ripe for future trips and projects that can further the geopolitical commentary about the global performativity of the laden militaristic connotations being played out post-Cold War that is beyond concepts of the voyage.

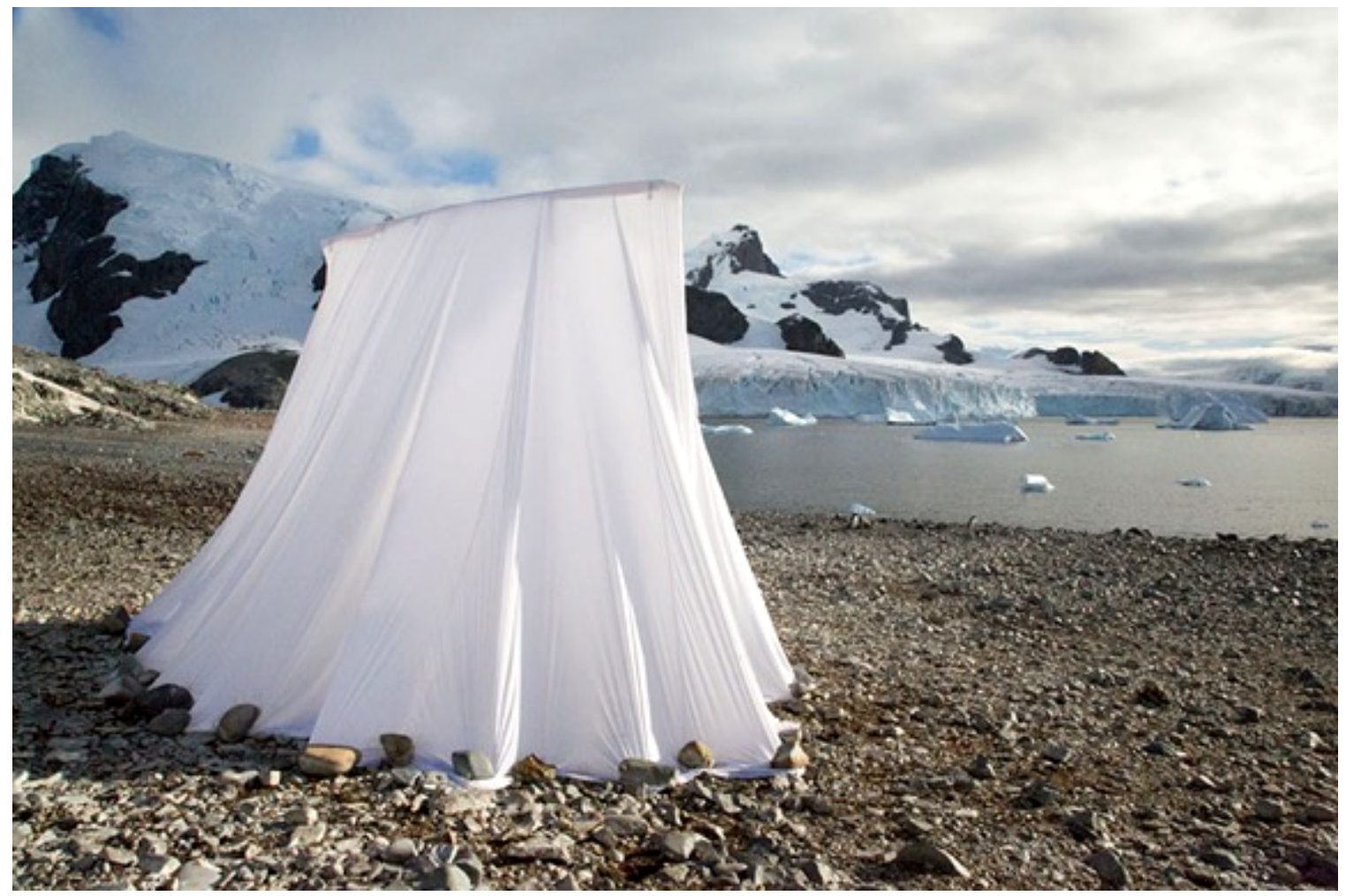

Figure 17. Gustav Dusing (Germany), The solid state of matter, 2017. Tent made of frozen cotton. Photo courtesy of the Artist and the Antarctic Biennale.

Certainly, Michel de Certeau would have had a field day and would have made further strides in interpreting semiotics of space with an example of the Antarctic biennale expedition, read as a practice of everyday life; the Antarctic timeless space would have transpired into an official place policed for multinational cooperation. In this case, the particular place is activated by the artistic interpretation of space in the most de Certeau-ian sense. ${ }^{104}$ The supranational union of Antarctica is undeniably a scientific one. The art biennale however, furthers the historic art and science dichotomy with recognition that art as its own science. 
Samman mentions, "The Antarctic Imaginary belongs to everyone, and yet control over the regime of images associated with it is centralized. For the most part, mimetic production is supplied by documentary photographers and filmmakers 'embedded' within scientific brigades, or else adhering to hegemonic interpretive frames." 105 His attempt therefore, to "[call] artists to "seize the means of south polar (image) production""106 is one with pure intension to strip away the already existing national competition that takes hold of the image of the other for power and control in scientific terms. In such light, it is helpful to think about Michael Taussig's consideration of the magic of mimetic reproduction to possess the other, in the face of mimetic alterity, ${ }^{107}$ meaning dispelling power in an image possibly taken out of its original intent and context. Take as an example that of the artist newly creating images that for artistic purposes; these can challenge the scientific capital investments and ventures as the latest make-up of the continent's existing purpose- creator of the ultimate Antarctic image.

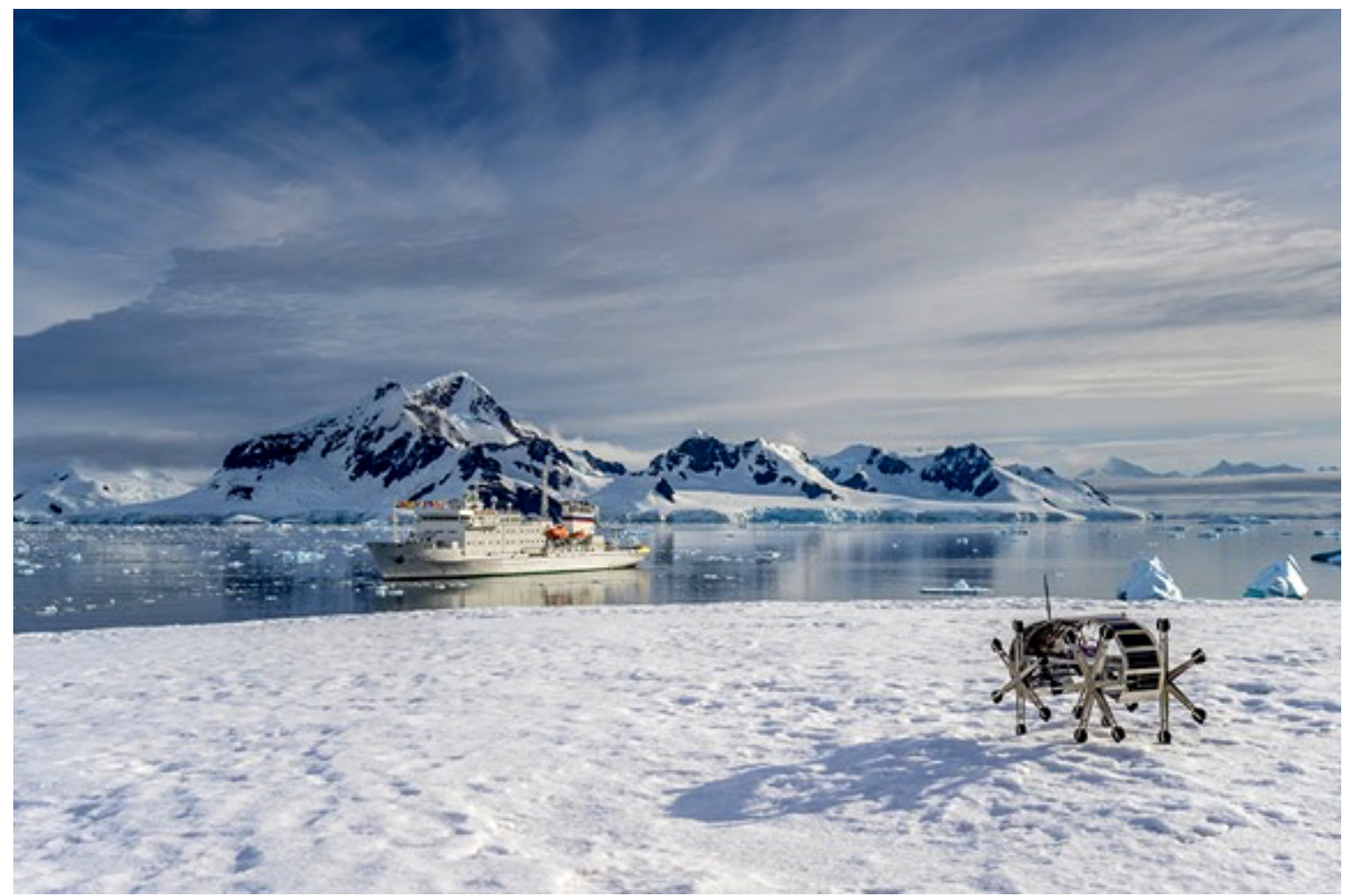

Figure 18. Joaquin Fargas (Argentina), Glaciator, 2017. Robotic and solar, mixed techniques. Photo courtesy of the Artist and the Antarctic Biennale.

The endless list of artist participants in all their capacities is also impressive. Ironically, the Antarctic Pavilion representation was not by one or two or a small group of artists like most of the other national pavilions at the Venice Biennale, rather the representation was worldwide. And, while the Antarctic Biennale was operating in opposition to the older biennale paradigms, they just up and created themselves their own biennale that includes artists representing every possible country, and showing works of all kind. ${ }^{108}$ 
The Antarctic Biennale artist lists includes these categories: the open call artists-finalists list, ${ }^{109}$ contributing artists list who were artists who sent their pieces of video art to be shown during the trip, ${ }^{110}$ interdisciplinary participants such as architects, film makers, philosophers, writers invited by the organizing committee, ${ }^{111}$ as well as the core group of artists-participants in the $1^{\text {st }}$ Antarctic Biennale includes artists and their projects who were the artists on the ship, selected by the Artistic Advisory Board. ${ }^{112}$

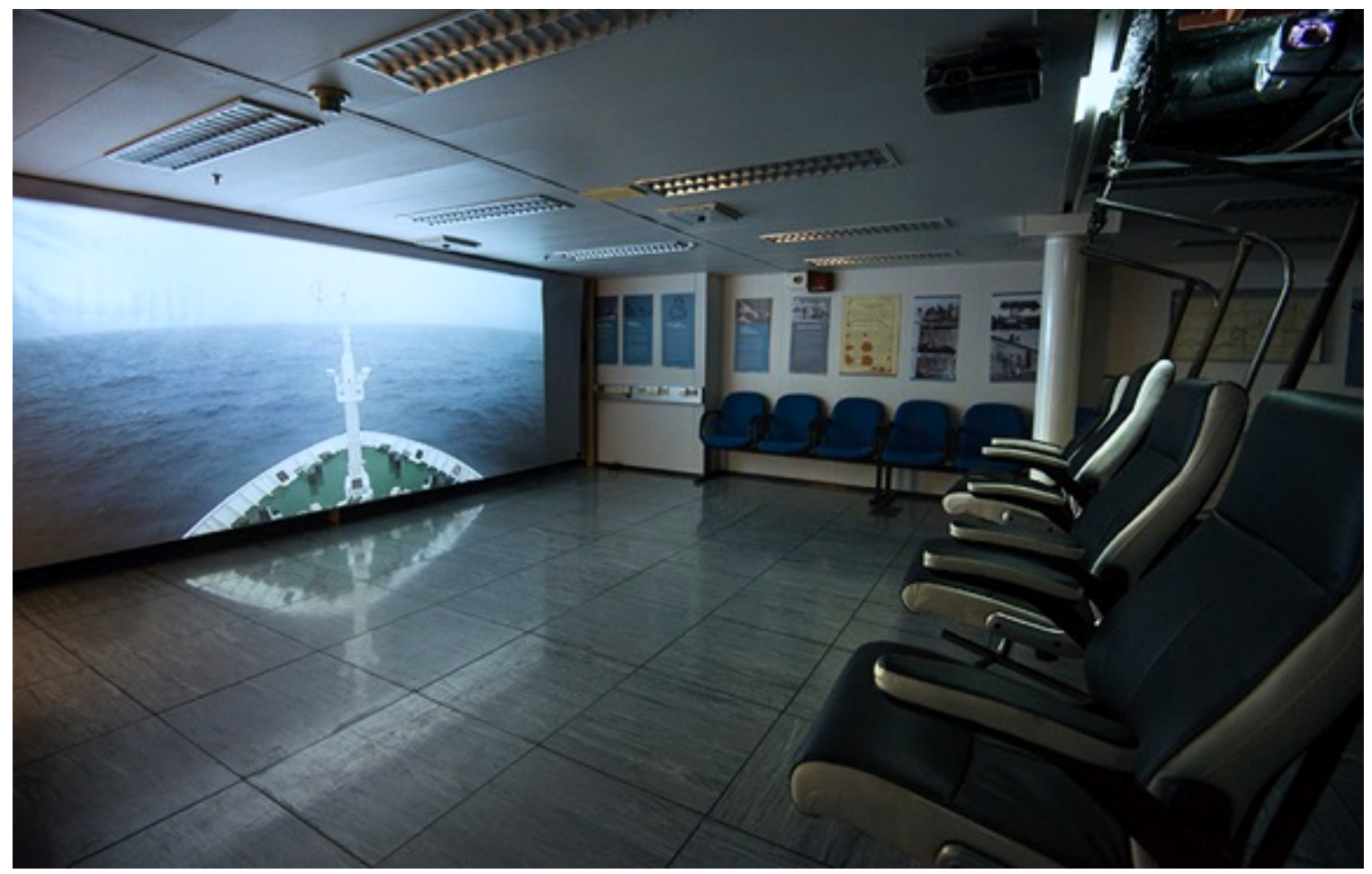

\section{Figure 19. Juliana Cerqueira Leite (Brazil), Vestibule, 2017. Video installation. Photo courtesy of the Artist and the Antarctic Biennale.}

One of the interdisciplinary artists, Miguel Petchkovsky writes about "Crossing Over on the Imaginary to the Intangible Reality" that "The Antarctic Biennale has opened new boundaries within a framework of the perception of time and physical (yet imaginary) space in which the reality was fluid and dense at the same time, alerting our senses to the wonder of nature, intangible by any definition. The overwhelming image of the magnitude and scale of the space has had a profound impact on oneself, reminding us that this equilibrium is fragile, eroded by human ambition and neglected by irresponsible political world leaders only interested in domination and conquest." 113 In fact, for Ponomarev, removal of the social and political sphere into full spatial and timeless experience was key proponent for creativity, an opportunity of purity and isolated creation activity that superseded everything else related to life, that propagated him and for many of those on board, a meaningful cause as a pathway towards an uncorrupt future, as he explains, "Suddenly we experience the entirety of being here and now with a sharp vision of art and creativity. According to Gibran Khalil Gibran, here is where the art may 'pass through nature to eternity."'114 
Regarding the essence of time, a marker of mapped Cartesian space, Ponomarev exclaims, "Actually, there is no time in Antarctica. All meridians converge to one point, time zones disappear, and navigation is becoming more and more difficult. The navigation and voyage turn into the core process - an adventure taking us far away from our ordinary time into the stream of immediate existence." 115

While there is the philosophical construct of the imaginary in terms of human creative imagination, or the media scholarship that conjoins the imaginary with desire, fantasy, and the virtual - where nation is concerned - it is imagined prior to its formation and it by imagination it is formed. Hence, the concept of nation as imagined, means that there is no cultural tabula rasa, even in the case of the Antarctic.

According to Anderson, all nations are performing, since there is no such thing as a real and original nation. As a concrete example of a performing nation, physically it can be seen with the change of the shape of the borders or the contours outlining the map of a nation itself and beyond the physical, nations disappear, are conquered and colonized. ${ }^{116}$ A nation is imagined as limited, sovereign, and "communities are to be distinguished, not by their falsity or genuineness, but by the style in which they are imagined," constructed by history, imagined, and performed. ${ }^{117}$ Taking that a step further into a polemical extreme, Ernest Gellner claims that "Nationalism is not the awakening of nations to self-consciousness: it invents nations where they do not exist."118

From the massive list of artists who participated in varying degrees, to comment on a select few of the individual projects that were performed and exhibited at the Antarctic, the beauty of seeing Sho Hasegawa skating on ice of Antarctica and Andrey Kuzkin's world turned upside-down, a headstand on ice (hats off to Geoffrey Hendricks headstand performances) ruptures and gives pause to the pictorial glacier landscapes. There is great humor in Sybren Renema's neon sign that is a self- reflective sign "Great God This is an Awful Place" in the middle of nowhere; it probably helped many artists who were ready to give up. The greatest formal and minimal abstraction soft sculpture piece made to this date is by Tomas Saraceno whose floating black areocene sculptures are aesthetic molds and smart, sustainable as air-fuelled carbon-emissions-free cubic floaters. Ponomarev's Alchemy of Antarctic Albedo (Washing Pale Moons), featuring metallic spheres that bounced around undersea as toys for whales is cinematic. As brilliant art pranks go, an exhibition for penguins, and introducing encapsulated tropical flora on Antarctica in Arribal by Paul Rosero Contreras seems fitting as a controlled move to place something foreign, contrasting well in its place, as well as its contradicting environment.

Moreover, there are three other intriguing art projects by different artists Julian Charrière, Julius von Bismark, and Juliana Cerqueira Leite, involving a coconut ballistic cannon, a goldfish, and motion stabilized chairs. Charrière's The Purchase of the South Pole was an art piece attempted to launch the first weaponized coconut fired out of a cannon, as "the first person since the signing of the Antarctic Treaty to fire a weapon in Antarctica." 119 While the cannon itself was confiscated by the German police before the departure, the relevancy of this piece still holds even unrealized. Von Bismark's Space Fish performance includes an incubated freshwater goldfish to swim in the Antarctic Sea. The custom designed and temperature controlled bowl allowed the fish to swim in its own fresh waters while being in salt waters with other fish. There is a kind of untampered beauty to seeing a water fish swim in the vastness of the sea. Lastly, Leite's site-specific installation inside the boat, called Vestibule, included motion stabilized chairs that drastically 
changed the experience of the boat, where the people seated in the chairs would go into reverse motion, where the body's rocking with the boat would stop and the entire boat would swing side to side. Seeing a screen in front of you with a stable horizon line of the outside ocean and sky for the first time in the voyage gave pause to everyone and an opportunity to rethink their spatial relations, providing contemplation about relativity of motion and gravitational force.

Von Bismark's earlier comment, that "we were placed, not displaced" was elaborated with "we were all placed purposefully" with attending to art projects, and whereas the expedition took artists out of their ordinary life and art practice, what the artists found, he said, was each other. Ponomarev, in his interview, spoke about being on the edge of the world and making art that is also on the edge, and that the Antarctic project was dedicated to the raw action of creating art, separate from cultural agendas, society, and politics, and science. For him, he was entering infinity leaving behind all man-made constructs, and through this fundamental return, to cosmology, the action and gesture of art, as documentation in the biennale was providing a "reflection" that is beyond anything that can possibly be in a show. As a complementary viewpoint to Ponomerav's, curator Samman naturally sees Antarctica as a "cultural space," that undermines the actual Venice Biennale, "sovereignty-obsessed relevant two centuries ago."120 The two perspectives conjoined as the presentation of the $1^{\text {st }}$ Antarctic Biennale where the underlying principles of supranationality, interdisciplinarity, intercultural exploration, and mobilis in mobile (meaning 'moving amidst mobility,' is the attempt to leave no traces behind after the event and installation of exhibition and art) were delivered in absolution. ${ }^{121}$

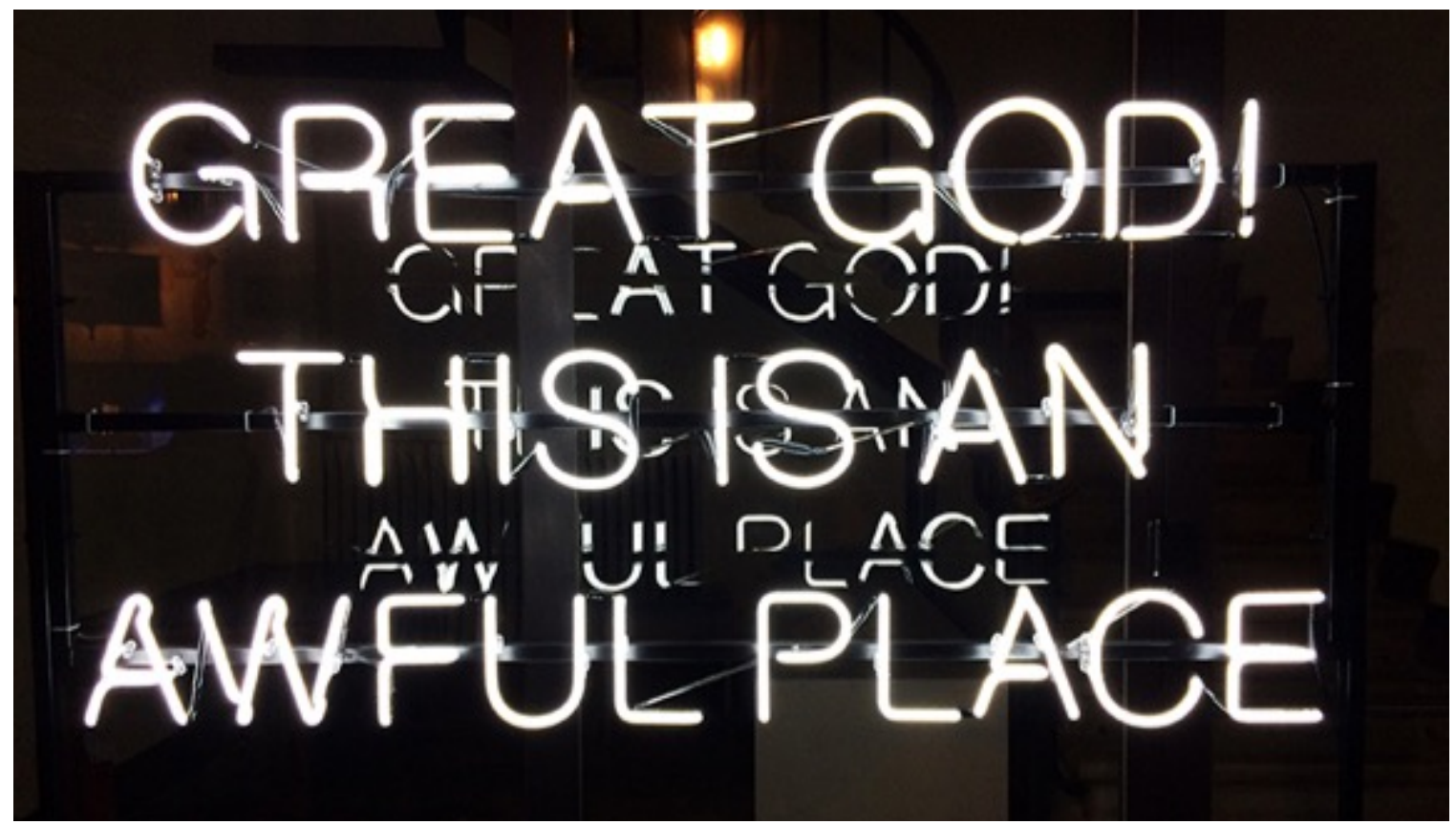

Figure 20. Sybren Renema (Netherlands), Great God! This is an awful place, 2017. Neon. 


\section{CONCLUSION}

The official list of the Venice Biennale 57 $7^{\text {th }}$ Art Exhibition included Christine Macel's "Viva Arte Viva," National Participations such as those of Korea and the United States of America, and extended to Official Collateral Events including the Antarctic Pavilion. There was actual outsider's visionary art in the main exhibition, as well as outsider's art on the streets, a lot of "sleep projects" (in and out of the main show) including Hans Ulrich Obrist and Hou Han Ru's secret presentation of Sleep with Frank Fu, ${ }^{122}$ which apparently was not so secret since it went from the Guggenheim to the Arsenale, and all of Venice ended up sleeping with this guy.

Any art within Venice leading up to the Biennale, anything showing from spring to summer, warrants attention since it belongs to the scene of the Biennale one way or another. Another collateral event "Glassstress," first debuted in 2009 and has continued with a growing list of international artists who revive the traditional craft of Murano glassblowing and showcase new glassworks. As well as having returning artists, this year's new artist participants included an international roster of artists including Ai Weiwei, Charles Avery, Sarah Sze, and Dustin Yellin. Yellin contributed with works that transcended and pushed the boundaries of his medium. His glass sculptures, Studies of Landscapes, enclose entire universes he meticulously cuts and pastes, manifesting in submersive subterranean or fleeting floating worlds, very Bosch-like but by intricate collaging done by using images of print from everywhere that he recycles to create complex world systems in between sheets of glass, forcing two-dimensionality into a totalizing virtual and immersive experience that you would think would be otherwise impossible as analog. ${ }^{123}$

Art projects further resonating the spirit of The Salon des Refusés, without approval and stamping of a national pavilion or invited curation of the main Biennale sites manifested in many different ways. Richard Humann's Augmented Reality (AR) piece Ascension, ${ }^{124}$ curated by Seol Park and using the Membit App designed by Jay Van Buren took over Venice as there were thirteen locations where people could pull out their phones to see a series of twelve constellation images in the sky with the thirteenth location including all of the floating images at one site seen right outside the Basilica di San Giorgio. Humann's breathtaking AR scenery above the waters and site line stands aloof as the largest AR piece to scale created so far, and the subversive viewing method of art paves way to a complete audience compliant art appreciation that only goes on at night. "The Limited Liability Pavilion: Identification - Young Generation of Artists from Kazakhstan" curated by Vladislav Sludskiy and Olga Vesselova, featured two young Kazakhstani artists Zoya Falkova and Anvar Musrepov in an apartment exhibition that implanted the seeds to yet another national pavilion in the future making. ${ }^{125}$

For the three distinct Pavilions, the Korean, American, and the Antarctic, fully promised in this essay for an enriched culturally nuanced comparative, the question of refuse, refusal, refugee, refuge, spoke out in small to big ways. What the essay is not doing is covering the Biennale through a usual short feature; rather the subject warrants a deeper and lengthier read for the labor and love, a sincere response to the scale and depth of the covered projects. 
New media scholarship is in an interesting crossroads for transposing all digital dialogs, social networking, and connection in and outside the screen as well as expounding on questioning what is the virtual condition that extends even to the nation's virtuality and political streaming. Theoretical undertakings of new media art, practice, and scholarship especially with postcolonial perspectives challenge global grand narratives, question ideological constructs, and look to new media and the social platform as a possible terrain for corrective cultural actions. We live in a world of intellectual poverty, often assigned to the problems of the screen, yet it is the very same technology that can direct us to generate new media discourse and knowledge, where technology societies shape content and ethics.

\section{REFERENCES AND NOTES}

1. On May 11 2017, in celebration of the new President Moon Jae-in of the Republic of Korea, Mina Cheon introduce to the world "Jae Son" (pronounced Jason), her boy art persona and writer, number one son of the patriarchal order, who assumes masculine power and simultaneously undoes it. Born May 20, 1972 Seoul, South Korea, his first international public appearance is at the Venice Biennale 2017 at the Australian artist Andrew Rogers's reception at the Palazzo Mora, Strada Nova, and authors this essay soon thereafter.

2. Anne Leader, "May 15, 1863 Paris's Salon des Refusés Opens," in Great Events from History: The 19th Century, 1801-1900, 4 Volumes, edited by John Powell (Pasadena, CA: Salem Press, 2007), 1100.

3. The works that are noted at the Venice Biennale to directly relate to the refugee crisis and Syria includes the South Africa Pavilion representations: Candice Breitz video installations with interviews of Syrian refugees as well as the works by Mohau Modisakeng, where the Pavilion exhibition reflects "on experiences of exclusion, displacement, transience, migration, and xenophobia," (Tyburn Gallery) written by Hili Perlson, "Candice Breitz and Mohau Modisakeng Will Probe South African Identities at Venice 2017," in artnet.com, November 3, 2016. https://news.artnet.com/art-world/south-african-pavilion-venice-biennale-2017-731864. Another source includes: Tim Leibbrandt, "Venice Biennale 2017: ArtThrob chats to South African Pavilion Curator Lucy MacGarry, April 21, 2017.

https://artthrob.co.za/2017/04/21/venice-biennale-2017-artthrob-chats-to-south-africa-pavilioncurator-lucy-macgarry/

4. Another example of biennale project involving migrants and refugees is Olafur Eliasson's Green Light workshop for migrants and refugees.

5. John Holten writes "The future of the planet, however, felt quietly sidestepped in Christine Macel's central exhibition. Rather a more subjective, atomized take on contemporary activism prevailed. This was epitomized by Olafur Eliasson's woefully misplaced Green Light workshop, which - though no doubt well-intentioned - felt awkward. Taking up one the first rooms of the Central Pavilion in the Giardini, migrants and refugees sat around assembling flimsy lights with bemused and curious art cognoscenti. These were in turn available to buy for $€ 250$, the proceeds going to legal aid for local refugees," in "What Happened to the Anthropocene? Searching the 57th Venice Biennale for Signs of Destruction," Momus, May 17, 2017. http://momus.ca/happened-anthropocene-searching-57th-venice-biennale-signs-destruction/ 
6. Personal interview with Lee Daehyung, the curator of the Korean Pavilion, took place on site, Venice Biennale, May 12, 2017.

7. Three succinct sources of criticism for Ai Weiwei's photomontage include the following. Ryan Steadman, "Ai Weiwei Receives Backlash for Mimicking Image of Drowned 3-Year-Old Refugee," in Observer, February 01, 2016. http://observer.com/2016/02/photo-of-ai-weiweiaping-drowned-refugee-toddler-draws-praise-ire/ "Ai Weiwei poses as drowned Syrian infant refugee in 'haunting' photo," in The Gaurdian, January 31, 2016.

https://www.theguardian.com/artanddesign/2016/feb/01/ai-weiwei-poses-as-drowned-syrianinfant-refugee-in-haunting-photo Sara Malm, “'Lazy, cheap, crass': Chinese artist Ai Weiwei is condemned for 'disrespecting' the memory of Syrian migrant Alan Kurdi by recreating haunting photograph of his washed up body," in MailOnLine and Associated Press, February 1, 2016. http://www.dailymail.co.uk/news/article-3426557/Chinese-artist-imitates-photo-Syrian-toddlerbeach.html

8. After much debated controversy, Calvin Tomkins's writes a response piece that explains, "Why Dana Schutz Painted Emmett Till, in The New Yorker, April 10, 2017 Issue.

http://www.newyorker.com/magazine/2017/04/10/why-dana-schutz-painted-emmett-till

9. A clear description of the VR piece with "Here's what goes down" is written by Alexndra Schwartz, "Confronting the "Shocking" Virtual-Reality Artwork at the Whitney Biennial," in The New Yorker, March 20, 2017. http://www.newyorker.com/culture/cultural-comment/confrontingthe-shocking-virtual-reality-artwork-at-the-whitney-biennial

10. Ai Weiwei appropriated Gangnam Style video in 2012 and there was no real hype nor controversy there, everyone was doing it, of course he would as well, but when an oversized Chinese man, an international art figure poses as a dead child washed up on the shorelines of Lesbos, there is a cultural sensitivity issue and the inappropriateness that becomes about the absence of the child's body in way that doesn't say more about the situation rather less. The thickness of Schutz's paint which seen from the side view is a low mountain, directs the work as a painterly gesture rather than a contextual commentary or motivated referencing for conscience framing. The lack of research and reference; it remains an aloof sign of controversy by glossing over the image with globs of paint. The danger of brutality in VR is Diane Gromala's coining of simsickness (simulation sickness) at extreme not really inducing actual PTSD, and how is it similar and different than many first hand shooter violent video games that played everyday, an inoculation of the violent media world we already live in, this time we can't escape it rather face it directly in the VR helmet where the assaulted victim is looking right at the viewer as if the observer is responsible. Diane Gromala writes, "Simsickness (or simulation sickness) refers to the proprioceptive determinations of the body receiving two sets of signals at odds with each other, one originating from the "real" world, say, gravity, the other from visual cues in the simulation that can produce the sensation of flying. The result is nausea, though the body usually adapts through habituation," in "Pain and Subjectivity in Virtual Reality," in Clicking In: Hot Links to a Digital Culture, ed. by Lynn Hershman Leeson (Seattle: Bay Press, 1996), 230.

11. "Treasures from the Wreck of the Unbelievable Damien Hirst," curated by Elena Geuna, at Palazzo Gassi and Punta della Dogana, Venice Biennale 2017, exhibition pamphlet, 3.

12. Incidentally, uncanny similarity to Hirst's work at the Venice Biennale by Jason deCaires was highlighted by Ben Davis, “An 'Unbelievable' Coincidence? Damien Hirst's Venice Show Looks Almost Exactly Like the Grenada Pavilion,” in artnet.com, May 16, 2017. 
https://news.artnet.com/art-world/damien-hirsts-unbelievable-coincidence-with-the-granadapavilion-

962066? utm content $=$ from \&utm source=Sailthru\&utm medium=email\&utm campaign=May 17, 2017 artnet News Daily Newsletter Excl Euro\&utm term=Ne

13. Exhibition website: http://www.palazzograssi.it/en/exhibitions/current/damien-hirst-atpalazzo-grassi-and-punta-della-dogana-in-2017-1/

14. The contested conjoining of the terms "art" and "activism" is questioned by many people in the art world. While the two things don't have to be the same thing, the current trend includes both forces as a part of the contemporary art discourse as they are being defined in today's cultural terms. Rowan Markson writes, "To What End Does Ai Weiwei Use Art for Activism or Activism for Art?" in New Minds Eye.

https://newmindseye.wordpress.com/to-what-end-does-ai-weiwei-use-art-for-activism-oractivism-for-art/

15. Cody Choi's entrance installation of the Korean Pavilion is the sensational site-specific piece Venetian Rhapsody: Power of Bluff.

16. "Biennale Arte 2017, Venezia: Giardinia, Arsenale," exhibition pamphlet, introduction by Christine Macel, 3.

17. Hettie Judah points to the trans-pavilions saying, "At its most benign and jubilant, the theme of sexual reawakening at this Biennale corresponds to an overarching Haight-Ashbury atmosphere in the central "Viva Arte Viva" exhibition. There are "trans-pavilions" dedicated to such switched-on delights as Earth, Commons, and Shamanism. At the Dionysian pavilion-a section celebrating the joys of the female body and intoxication - progressive, liberated sexuality is explicitly a counterpart to the wider exhibition's woke socio-political instincts" in "The Turned-On Biennale: An Orgy of Liberal Sex and Liberal Guilt Greets Visitors in Venice," in artnet.com, May 14, 2017.

https://news.artnet.com/exhibitions/the-x-rated-biennale-venice-2017-

960158?utm campaign $=$ artnetnews\&utm source $=051517$ daily\&utm medium $=$ email\&utm conte nt=from \&utm term $=$ artnet $\% 20$ News\%20Daily\%20Newsletter\%20USE

Tess Thackara also writes about the artists role in the exhibition, "Artists are the central protagonists in the overarching picture that Macel gives of human experience, which she has broken down across the Giardini's Central Pavilion and the Arsenale into several themes: the Pavilion of Artists and Books, the Pavilion of Joys and Fears, the Pavilion of the Common, the Pavilion of Earth, the Pavilion of Traditions, the Pavilion of Shamans, the Dionysian Pavilion, the Pavilion of Colors, and the Pavilion of Time and Infinity," in artsy.net, May 11, 2017. https://www.artsy.net/article/artsy-editorial-venice-biennale-ecstatic-celebration-artists-falls-trap 18. The vibe of magical healing surrounded the main exhibition sties. Ben Davis writes about "Macel's therapeutic vision" in "In the Venice Biennale's 'Viva Arte Viva,' Shamanism Sneaks Back Into the Picture: Primitivism makes an unexpected return in Christine Macel's therapeutic vision," in artnet.com, May 12, 2017.

https://news.artnet.com/exhibitions/venice-biennale-2017-viva-art-viva-review-

958238?utm campaign $=$ artnetnews\&utm source $=051217$ daily\&utm medium $=$ email\&utm conte $\underline{\text { nt }}=$ from \&utm term $=$ New US Newsletter List

19. Tess Thackara, "The Venice Biennale Is an Ecstatic Celebration of Artists That Falls into Its Own Trap" in artsy.net, May 11, 2017. https://www.artsy.net/article/artsy-editorial-venicebiennale-ecstatic-celebration-artists-falls-trap 
20. In relation to himself, Michele Ciacciofera explains Janas Code in his project statement that "Assuming that there is no knowledge of human culture if not through the awareness of places, environmental contexts, and the passing down of the collective memory that regards them, the legends of Janas are inscribed into the age-old evolution of this Mediterranean island's unique culture. Sardinia is my native land, and her traditions and influence have accompanied me throughout my life, since I left the island as a young child. The maternal stories of fairies have never stopped fueling my imagination, and they often bring me to visualize a shamanic coexistence with these beings ... ... The body of work I am referring to includes all of the elements listed above: bees, stones, ceramics, rooms, houses, carpets, books, furnishings, clothing, and fantastical objects, all gathered within a domestic sphere in which the exhibition searches to allow a complete experience, that doesn't wander from, or overlook the simplicity of the culture of reference ...... This project aims to build a bridge between the historical, anthropological, and archeological aspects of the research, and the converging themes of memory and play." An image of the installation can be found here: http://u-in-u.com/venicebiennale/2017/viva-arte-viva/photos-arsenale-1/michele-ciacciofera/

21. Lee Mingwei, The Mending Project, "The otherwise mundane act of mending is being transformed into a device that triggers meaningful personal narratives as well as the possibilities of emotional resonance," statement with the work.

http://www.janelombardgallery.com/news/2017/5/19/lee-mingwei-at-57th-venice-biennale-may13-november-26-2017

22. Gayatri Gopinath, Impossible Desires: Queer Diasporas and South Asian Public Cultures (Durham and London: Duke University Press, 2005).

23. Gopinath, ibid., 5.

24. A solid description of the American political landscape and meaning of Mark Bradford's installation can be found in the review by Alexander Forbes, "While Bradford has said that he doesn't intend the pavilion to represent his nation or even any universal experience of African Americans, it's hard not to read the pavilion as a sort of ghost town of Barack Obama's America, where some signs of progress or at least processing of injustices and prejudice are slowly being squeezed out of view by the python-like coil that fills the rotunda's dome. As much as Bradford's pavilion reflects or at least exists within the context of an increasingly nationalist, isolationist, and authoritarian U.S. government that by the day takes two more steps back from what was an increasingly progressive society, Bradford's pavilion is also the locus point of a step forward," in "A New Nationalism Is Brewing at the Venice Biennale-But It's Not the Kind You Think," in artsy.net, May 12, 2017. https://www.artsy.net/article/artsy-editorial-new-nationalism-brewingvenice-biennale-kind

25. Andrew Goldstein, "Mark Bradford Is Our Jackson Pollock: Thoughts on His Stellar U.S. Pavilion at the Venice Biennale," in artnet.com, May 11, 2017.

https://news.artnet.com/exhibitions/mark-bradford-is-our-jackson-pollock-thoughts-on-his-stellaru-s-pavilion-at-the-venice-biennale-957935

26. Google definition of Supranational is "having power or influence that transcends national boundaries or governments," google.com.

27. Benedict Anderson, "Apprehensions of Time," in Imagined Communities: Reflections on the Origin and Spread of Nationalism (London and New York: Verso, 1996), 22.

28. Same interview with Lee Daehyung, May 12, 2017.

29. Anderson, ibid., 205. 
30. Anderson, ibid.

31. Song Dong, artist statement, Gwangju Biennale 2006: Fever Variations, catalog.

32. Theresa Hak Kyung Cha, Dictee (Berkely and Los Angeles: University of California Press, 2001).

33. Melissa Chiu, "Theories of Being Outside: Diaspora and Chinese Artists (2007),"

Contemporary Art in Asia: A Critical Reader, edited by Melissa Chiu and Benjamin Genocchio

(Cambridge, Massachusetts: The MIT Press: 2011), 329.

34. Chiu, ibid., 330.

35. Inderpal Grewel and Caren Kaplen, Scattered Hegemonies: Postmodernity and

Transnatioinal Feminist Practices (Minneapolis and London: University of Minnesota Press, 2001), 11.

36. Grewel and Kaplen, ibid., 13.

37. Grewel and Kaplen, ibid., 7.

38. Gennifer Weisenfeld "Reinscribing Tradition in a Transnational Art World (2007),"

Contemporary Art in Asia: A Critical Reader, edited by Melissa Chiu and Benjamin Genocchio (Cambridge, Massachusetts: The MIT Press: 2011), 372.

39. Alison Carroll assembles a television and DVD series "A Journal through Asian Art" in 2014 and speaks up about how Western artists uses Eastern ideas for art it was considered avant-garde but when Asian artists uses Western art techniques, considered inferior copiest works. Interesting thing about the Korean Pavilion is how there is no attempt to appropriating Westerness as it is so ingrained in Korean culture, the fusion just exists and exudes out in the open of the entire exhibition.

40. The outside of the Korean Pavilion, which is showing work by the artist Cody Choi, is covered in a neon work called Venetian Rhapsody, The Power of Bluff (2017) that beckons visitors to the Biennale by intimating that this is a hotel, with the following on services on offer: "POLE DANCE, FREE VIDEO TV, FREE NARCISSISTIC PEOPLE DISORDER, FREE PEEP SHOW, MAJOR CREDIT CARDS, FREE ORGASM." Nate Freeman mentions this piece in "The Korean Pavilion: Come for the Neon, Stay for the Pepto-Bismol," in artnews.com, May 5, 2017. http://www.artnews.com/2017/05/09/the-korean-pavilion-come-for-the-neon-stay-for-thepepto-bismol/

41. Counterbalance: The Stone and The Mountain Cody Choi Lee Wan, Korean Pavilion Biennale Arte 2017 exhibition catalog (Seoul, Korea: Arts Council Korea, 2017), 126.

42. "Cultural indigestion" was mentioned in the Artist Biographies for Cody Choi as a "new paradigm," in "Counterbalance: The Stone and The Mountain Cody Choi Lee Wan," in Korean Pavilion Biennale Arte 2017 exhibition pamphlet (Seoul, Korea: Arts Council Korea), 2017. 43. Taken directly from the words of Cody Choi during the Korean Pavilion opening while being interviewed, May 10, 2017.

44. Lisa Lowe, Immigrant Acts: On Asian American Cultural Politics (Durham and London: Duke University Press, 1996), 4-5.

45. Counterbalance, Korean Pavilion exhibition catalog, ibid., 189.

46. Counterbalance, Korean Pavilion exhibition pamphlet, ibid.

47. Counterbalance, Korean Pavilion exhibition catalog, ibid., 190.

48. Ibid., 187.

49. Andrei Lankov writes, "according to a recent study, 227 of the 457 coups worldwide between 1950-2010 succeeded. Two of those successful coups took place in the country Pyongyang 
watches most: South Korea," in "Kim Jong Un Is a Survivor, Not a Madman," in Foreign Policy, April 26, 2017. http://foreignpolicy.com/2017/04/26/kim-jong-un-is-a-survivor-not-a-madman/ 50. A white taxidermy dog stands in the middle of the exhibition room. Quite common to see dogs around the streets more so in the 70s of Korea, less so today as pets and companion animals have been adopted with the rise of Western influence in Korea, and people seem to eat less dogs today. But this white jindogae, says something, it is the abandoned stranger, things in Korea that are left behind since they are no longer a commodity or fashion. The dog symbolizes the minority, laborers in Korea (Philippines), the queer states of indefinable bodies and identities and those who cannot take on the role of the Confusion paradigm, those unrecognized as conglomerates and mountains, and corrupt politicians.

51. The U.S. Pavilion at the Venice Biennale mobilized a large team of efforts that included cocurator Katy Seigel, Senior Curator for Research and Programming of the Baltimore Museum of Art and with relations to Bedford's former museum, the Rose Art Museum at Brandeis University.

52. Andrew Goldstein, "Mark Bradford Is Our Jackson Pollock," in artnet.com, ibid.

53. Goldstein also wrote, "The most important thing about Mark Bradford's bravura, deeply felt presentation for the Venice Biennale's United States pavilion is that the bright spotlight of the occasion reveals him to be that thing America can use right now: a new Very Important Artist," ibid.

54. "Tomorrow is Another Day: Mark Bradford, U.S. Pavilion Biennale Arte 2017," exhibition pamphlet, 2.

55. In honoring the success of Mark Bradford, Chris Bedford spoke about artist is citizen during the U.S. Pavilion reception at the Peggy Guggenheim Collection in Venice, May 12, 2017. 56. The terms "White House" and "servant's entrance" are directly used in "Tomorrow is Another Day," exhibition pamphlet, ibid.

57. This is a response to Michael Fried's most infamous quote, "Art degenerates as it approaches the condition of theatre," in his contestable article, "Art and Objecthood," originally published in Artforum, June 1967, 12-23.

58. The title "Tomorrow is Another Day" has "is" for Pavilion title and "Is" for the painting title.

59. "Tomorrow is Another Day," exhibition pamphlet, ibid., 2.

60. Ibid., 6.

61. Kirk W. Fuoss, "Lynching Performances, Theatres of Violence," in Text and Performance Quaterly, January 1999, Volume 19 No.1, 4.

62. "Mark Bradford: Process Collettivo, Rio Terà dei Pensieri," The Rose Art Museum at Brandeis Univesity, The Baltimore Museum of art, U.S. Department of State's Bureau of Educational and Cultural Affairs, 2017, pamphlet, 6.

63. Rio Terà dei Pensieri (RTdP) is a social cooperative that provides opportunities of workplacement and social re-integration to men and women within Venice's prisons.

http://www.rioteradeipensieri.org

64. This is based on Mark Bradford remarks during a brief interview that was conducted after the Press Conference outside the U.S. Pavilion on May 11, 2017.

65. "Rio Terà dei Pensieri and Mark Bradford: A Collaboration," in Rio Terà dei Pensieri (Venizia and Los Angeles: RTdP and A+P, 2017), 36.

66. "Malefatte" is translated varying as "wrong made" in Press Release from RTdP as well as "misdeed" in Rio Terà dei Pensieri, ibid., 27. 
67. Mark Bradford's six-year collaboration of Process Collettivo includes working with existing programs at RTdP such as the Silkscreen Lab (Hand-made printed shopping bags and t-shirts are made by male prisoners); Bag Manufacturing Lab (PVC and other recycled materials are used by male prisoners to create unique and original accessories); Produce Garden (The garden is certified organic and fruits are offered for sale by the female prisoners); Cosmetics Lab (High quality and handcrafted beauty products are inspired by the ancient tradition of Venetian apothecaries and enriched by natural extracts from the garden. These products are made by the female prisoners. There are two different lines of cosmetics: RTDP Classical and Eco-Organic in addition to customized offerings for the hotels). The description is taken directly from the Press Release from RTdP.

68. "Four Reasons to be Interested in a Prison-Based Economy," in Rio Terà dei Pensieri, ibid., 6.

69. Michel Foucault, "Panopticism," in Discipline \& Punish: The Birth of the Prison, translated by Alan Sheridan (New York: Vintange Books, 1979), 195-230.

70. Angela Y. Davis in Abolition Democracy: Beyond Empire, Prisons, and Torture (New York, NY: Seven Stories Press, 2005).

71. Davis, ibid., 95.

72. Davis, ibid., 94.

73. Pablo Helguera, Education for Socially Engaged Art: A Materials and Techniques Handbook, (New York, NY: Jorge Pinto Books, 2011), 3.

74. "Mark Bradford: Process Collettivo, Rio Terà dei Pensieri," pamphlet, ibid., 5.

75. Ibid., 6.

76. Ibid.,12.

77. Pietro was his temporary name assigned to him during his visit to the Venice Biennale who I had the opportunity to interview at the U.S. Pavilion site on May 11, 2017. As a free man today, using his rightful name Popescu Petrica, he was let out from prison on June 27 and still working with Mark Bradford at the U.S. Pavilion in Venice.

78. "This outstanding program has inspired internationally renowned American artist Mark Bradford, who will represent the United States at the $57^{\text {th }}$ International Art Exhibition " $\mathrm{La}$ Biennale" in Venice from May 13 to November 26, to become a passionate supporter of the project," Press Release from RTdP.

79. Amy Goodman and David Goodman, Standing Up to the Madness: Ordinary Heroes in Extraordinary Times (New York, NY: Hyperion, 2008), 1.

80. Jerry Saltz writes in "Eric Fischl's Great New Work of American Art Can Only Be Seen on Facebook-And Here," in Vulture, December 20, 2016. http://www.vulture.com/2016/12/ericfischls-new-master-portrait-of-america.html

81. Amy Goodman and David Goodman, ibid., 219.

82. Ibid., 228.

83. Helguera writes, "Social work is value-based profession based on a tradition of beliefs and systems that aim for the betterment of humanity and support the ideals such as social justice...... An artist, in contrast, may subscribe to the same values but make work that ironizes, problematizes, and even enhances tensions around those subjects, in order to provoke reflection," in Education for Socially Engaged Art, ibid., 35.

84. Ibid., 53.

85. We take the Kaprownian spin on "The education of the un-artist," part 2, in Essays on the Blurring of Art and Life (Berkeley: University of California Press, 1993) and pay attention to the 
new ways art and life intersects at moments of art for social engagement for justice as a calling of our contemporary times where an artist's activism is resistance.

86. Allan Kaprow writes "Experimentation also involves attention to the normally unnoticed" and that "Playing with everyday life often is just paying attention to what is conventionally hidden," in "Just Doing," The Performance Studies Reader, ed. by Henry Bial (London and New York: Routledge, 2004), 141.

87. The 1st Antarctic Biennale press release states, "The project incorporates artistic, scientific, and philosophical methodologies to address the concept of 'shared spaces' such as Antarctica, the Ocean and the Cosmos. The 1st Antarctic Biennale departs from standard exhibition models by re-imagining a traditional art event format. It is a creative journey that expands the parameters of what art can be today."

88. "Supranational: A cultural conceptualization of a space that doesn't belong to any single country. A model for a future world community," press release.

89. Written on website on The Antarctic Treaty from 1959, "The Antarctic Treaty was signed in Washington on 1 December 1959 by the twelve countries whose scientists had been active in and around Antarctica during the International Geophysical Year (IGY) of 1957-58. It entered into force in 1961 and has since been acceded to by many other nations. The total number of Parties to the Treaty is now 53. Some important provisions of the Treaty: "Antarctica shall be used for peaceful purposes only (Art. I) Freedom of scientific investigation in Antarctica and cooperation toward that end ... shall continue (Art. II). Scientific observations and results from Antarctica shall be exchanged and made freely available (Art. III). Among the signatories of the Treaty were seven countries - Argentina, Australia, Chile, France, New Zealand, Norway and the United Kingdom - with territorial claims, sometimes overlapping. Other countries do not recognize any claims. The US and Russia maintain a "basis of claim." All positions are explicitly protected in Article IV, which preserves the status quo: No acts or activities taking place while the present Treaty is in force shall constitute a basis for asserting, supporting or denying a claim to territorial sovereignty in Antarctica or create any rights of sovereignty in Antarctica. No new claim, or enlargement of an existing claim http://www.ats.aq/e/ats.htm to territorial sovereignty in Antarctica shall be asserted while the present Treaty is in force. " http://www.ats.aq/e/ats.htm 90. The Protocol on Environmental Protection to the Antarctic Treaty signed in 1991 can be found here: $\underline{\text { http://www.ats.aq/e/ep.htm }}$

91. Co-curator Nadim Samman writes, “According to the 1959 Antarctic Treaty, the southern continent is reserved exclusively for peaceful scientific research in the interest of all of humanity (with sovereign claims suspended). Owned by no individual or nation, but home in the summer months to approximately four thousand researchers, this legal and institutional framework (and its implementation) is the most successful example of international cooperation in modern history. This fact is even more impressive when one observes that the Antarctic Treaty was born at the height of the Cold War, when geopolitical tensions were most fraught." In "Mobilis in Mobile -

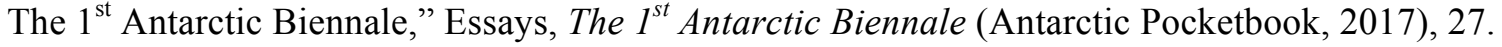
92. Star Trek, "Space: the final frontier. These are the voyages of the starship Enterprise. Its continuing mission: to explore strange new worlds, to seek out new life and new civilizations, to boldly go where no one has gone before." With more civilization and explorations of new worlds, the concern for anthropocene is raised as a concern. An interestingly related review is by John Holten "What Happened to the Anthropocene? Searching the $57^{\text {th }}$ Venice Biennale for Signs 
of Destruction," in Momus, May 17, 2017. http://momus.ca/happened-anthropocene-searching57th-venice-biennale-signs-destruction/

93. This is from an interview with Alexander Ponmarev, commissioner of the Antarctic Pavilion, at the Venice Biennale, May 12, 2017.

94. This is from an interview with two of the Antarctic Biennale artists, Julius von Bismarck and Juliana Cerqueira Leite, Venice, May 12, 2017.

95. Written in Newport, August 22, 2016, Foreword, The $1^{\text {st }}$ Antarctic Biennale, ibid., 15-16.

96. From the 1st Antarctic Biennale press release.

97. Nadim Samman, Antarctic Biennale Vision Club (ABVC), Issue 1, 2017, 8.

98. Ibid., 9.

99. The score for the expedition follows: "The Expedition, The ship will sail from the port of Ushuaia in Argentina, 54 $47^{\prime} \mathrm{S}, 68^{\circ} 17^{\prime} \mathrm{W}$, and pass through the Drake Passage. The Antarctic Biennale expedition will reach the Antarctic Circle, $66^{\circ} 3344 \mathrm{~S}, 67^{\circ} 30 \mathrm{~W}$, During landings at various Antarctic locations, artists will temporarily install art works, or engage in performances." In The $1^{\text {st }}$ Antarctic Biennale, ibid., 36-37.

100. Alexander Sekatsky, "Pure Contemplation Idea," starts with "Lecture read to penguins, Antarctica, March 22, 2017, in $A B V C$, ibid., 49.

101. Carol Rizzo writes, "We had just spent half an hour on a small island in complete silence (courtesy of Julian Charrière, who proposed this 'not-happening'). I've been searching for silence for a while, perhaps like most city people do, so I was grateful," ibid., 42.

102. The $1^{\text {st }}$ Antarctic Biennale, ibid., 42.

103. Rachel Gould writes, "This exceptional voyage explores virgin territory for the art world," in "The Art World Explores New Terrain on the Antarctic Biennale's Maiden Voyage," in The Culture Trip, March 28, 2017. https://theculturetrip.com/antarctica/articles/the-art-worldexplores-new-terrain-on-the-antarctic-biennales-maiden-voyage/

104. In his famous semiotic read of space in The Practice of Everyday Life, Michel de Certeau offers a new way of understanding the performativity of place as an experienced space of "spatial practice" (115) or "space [as] practiced place," where the proper of locality is displaced by the shared anthropomorphic scene that occupies and narrates a different kind of story-telling. The artists of the biennale were at the site of greatest space of performativity as the concepts of infinite space and timelessness, "seeing" and "going," diverge between reality and the imagination. Michel de Certeau, "Spatial Stories," The Practice of Everyday Life, trans. by Steven Rendall (Berkeley: CA, University of California Press, 1984), 115 - 130.

105. Samman, The $1^{\text {st }}$ Antarctic Biennale, ibid., 27.

106. Ibid., 28.

107. Michael Taussig highlights relevance to the power of the image based on the beholder in the postcolonial relationship between self and other, especially while looking at Cuna Indians who have gained power over the Western world by possessing the image of the Westerner, sometimes burning it, or attaining the other man's power by replicating its features in curing figurines known as nuchus. Michael Taussig in "In Some Way or Another One Can Protect Oneself From the Spirits by Portraying them," in Mimesis and Alterity: A Particular History of the Senses (New York and London: Routlegde, 1993), 1 - 19.

108. Making the mark as an official new Biennale of a new Pavilion is central in gaining presence, press, and future funding. Certainly this impressive list of artists from different countries makes “Antarctica" everyone's land, no man's land suffice. But, future work on the biennale can be two folds, one, to be well served by abolishing all national identities and taking 
on new names and personae of Antarctic exotic species or name of landmark for the opportunity for artists to fully integrate and respond to their site of concern or some other more appropriate artistic strategy that directly deals with the troubling identity of the continent and the apparent lack of political and social discussion on whose land it is, as it belongs to the co-nationalized treaty. Two, since "art" has been made in Antarctica, "culture" has landed, allow the artists to do something else.

109. Out of them selected 15 artists presented their works as documentation as a group exhibition during the 57th Venice Biennale of Art 2017: Andreas Lutz (Germany), Ariel Spadari (Brazil), Banrei (USA), Bridget Steed (UK), Jasmin Blasco (France), Louise Oates (UK), Matilde Solbiati (Italy), Meadhbh O'Connor (Ireland), Stefan Laxness (Iceland), Stephanie Roland (Belgium), Sybren Renema (Netherlands), Tomjo Blake (Australia), Valentine Siboni (France), Winston Chmielinski (USA).

110. Adrian Balseca (Eccuador), Cinemateque de Tangiers (Morocco), Constant Dullaart (Netherlands), Eli Maria Lundgaard (Norway), Emile Brout and Maxine Marion (France), Emmy Skensved and Gregoire Blunt (Canada), Etienne de France (France), Eva and Franco Mattes (Italy), Hans Op de Beeck (Belgium), Jessica Sarah Rinland (UK), Julian Charrière (France / Switzerland), Karin Ferrari (Austria), Katya Kovaleva (Russia), Marcel Dinahet (France), Paul Rosero Contreras (Ecuador), Swetlana Heger (Sweden), Young Hae-Chang Heavy Industries (Korea), Yto Barrada (Morocco).

111. Adrian Dannatt (UK), Alexander Sekatskii (Russia), Barbara Imhof (Austria), Carlo Rizzo (Italy/UK), Elizabeth Barry (USA), Jean de Pomereu (France), Hector Monsalve (Argentina), Lisen Schultz (Sweden), Miguel Petchkovsky (Angola/Portugal), Nicholas Shapiro (USA), Sergey Pisarev (Russia), Susmita Mohanty (India), Wakana Kono (Japan).

112. In the pursuit of a performing new art land, the works created in Antarctica certainly had a sense of community and the artists unraveled the potential of the Antarctic Imaginary with these projects: Abdullah Al Saadi (UAE), Antarctic Alphabets, expedition diaries; Alexander Ponomarev (Russia), Alchemy of Antarctic Albedo (Or Washing Pale Moons), underwater installations; Alexis Anastasiou (Brazil), It's Cold out There, large scale projection; Andrey Kuzkin (Russia), The Phenomenon of Nature or 99 Landscapes with a Tree, series of performances; Eulalia Valldosera (Spain), Penelope's voice: communicating with animals, audio intervention on the ship that travels to Antarctica; Gustav Dusing (Germany), The solid state of matter, tent made of frozen cotton; Joaquin Fargas (Argentina), Glaciator, robotic \& solar, mixed techniques; Julian Charrière (France/Switzerland), Silence, performance; Juliana Cerqueira Leite (Brazil), Vestibule, video installation; Julius von Bismarck (Germany), Space Fish (Raumfisch), performance; Lou Sheppard (Canada), Requiem for the Antarctic Coast, sound installation; Paul Rosero Contreras (Ecuador), Arriba!, site-specific intervention, film, photographs; Shama Rahman (Bangladesh/UK), Truth be told, performance with sitar on ice; Sho Hasegawa (Japan), Winter Landscape (Antarctica Version), site-specific performance; Tomas Saraceno (Argentina/Germany), Aerocene, performance; Yasuaki Igarashi (Japan), Bundling Time, performance; Yto Barrada (Morocco), Abstract Geology, fiber installation; Zhang Enli (China), Egg, sculptural installation.

113. Miguel Petchkovsky, "Time Frame in Mobile," in $A B V C$, ibid., 33.

114. Alexander Ponomarev, Russian English Document on philosophical ideas capturing "Biennale in Time," 2017, 1.

115. Ibid. 
116. People that constitute the country also move around, migration and citizenship are tied in ways that promote sovereignty with stability and order, yet communities imagined, placed, and displaced creates the heterogeneity of site and therefore can never be singular, totalized, one nation, nor can there be a superior race that bear the flag of a superior nation. Albert Memmi writes about this in Racism, in that "Racism is the generalized and final assignment of values to real or imaginary differences, to the accuser's benefit and at his victim's expense, in order to justify the former's own privileges or aggression" (169) and that "the very concept of biological purity for human groups is unfounded ...... In any case, suppose that a purity exists - how would one connect biological purity with superiority?" (188) In Albert Memmi, Racism, trans.by Steve Martinot (Minneapolis and London: University of Minnesota Press, 2000.

117. Anderson argues that a nation "is an imagined political community - and imagined as both inherently limited and sovereign," ibid., 6. Patriotism that is romanticized surrounding the home nation and state adopts a formula of nostalgia that returns to an original past of quintessential essence, thereby endorsing a classist and separatist world construct of those of the past who are historicized. Anderson points out that "nationalism think in terms of historical destinies, while racism dreams of eternal contaminations, loathsome copulations: outside history," ibid., 149.

118. Ernest Gellner, Thoughts and Change (169) cited by Anderson, ibid, 6.

119. Written in the artist's project statement, the proposed piece was a response piece and performance to Jules Verne's novel The Purchase of the North Pole (1889) where two founders of a company that bought the ownership of the Arctic wanted to blast with a major cannon so powerful to be able to "shift the Earth's rotational axis" and stir the grounds and get to the coal reserves underground.

120. Samman, statement on The Antarctic Pavilion. http://www.antarcticpavilion.com/about.html 121. Samman, writes that "the concept of "mobility in the mobile" - transportable installations that are quickly erected and dismantled respect Antarctica's fragility leaving no traces of the artistic activity on the continent," in "Mobilis in Mobile," ibid., 28, as well as listed as a part of the Principles of the Biennale from the press release that also includes key concepts of Supranationality, Interdisciplinarity, Intercultural Exploration.

122. Sleep with Frank Fu - From Guggenheim to Arsenale. http://cubub.com/image/BUGofVJ17$\underline{0}$

123. Kenneth Goldsmith writes about Yellin's work, "As much as Yellin connects with insiders like Alberti, Corbusier, Duchamp, and Krauss, his work is in dialogue with the rich tradition of maverick, outsider artists. His obsessive accumulations and decoupage of magazine elements into three-dimensional collages invoke the visionary works of Henry Darger, Martín Ramírez, Howard Finster, and, in particular, Alfred Jensen, whose handcrafted impasto renderings of complex mathematical notation were laid atop flat fields of geometric abstraction," in "Nose Pressed Up Against the Glass: Dustin Yellin's Metaphors of Opacity and Transparency." http://dustinyellin.com/essays/nose-pressed-up-against-the-glass.php

124. "Richard Humann creates an alternate universe within our own universe in his locationbased augmented reality (AR) multimedia installation, Ascension. The work consists of twelve imaginary constellations suspended in the sky over the magical city of Venice, and can be viewed using an augmented reality app, Membit, on a smart phone or tablet. The constellations that we recognize today are based on a 2,000-year-old mythology derived from the ancient Greeks. Their heroes, villains, mortals, and gods ascended into the sky for all eternity. Inspired by the seminal work of comparative mythology, "The Hero with a Thousand Faces" by Joseph Campbell, Humann superimposes a new constellation system over our existing one. He created a new 
mythology and the new folklore, by taking popular figures of the $20^{\text {th }}$ Century and then developed a visually metaphoric and encapsulated story arc that accompanies them." (Press Release) http://richardhumann.com/richard/works/ascension/

125. "The Pavilion of Limited Liability was conceived as a response to the lack of sufficient support from state institutions in the field of contemporary art. Eventually, the project resulted in an artistic understanding of the role of institutions in shaping the artist's view. This topic proved to be relevant not only to the context in Kazakhstan, but also to the entire post-Soviet space. In addition, it uncovered some other aspects of causes and consequences which have led to the current situation. The third stage of the project is an attempt to draw attention to the Kazakhstan art and to the lack of its representation as a national pavilion at the 57th Venice Biennale. On the other hand, it is a desire to show young Kazakhstan artists whose works are relevant not only to our country. The young art from Kazakhstan is not isolated from the world art process. It has something to say to the viewer outside the local community." (Press Release) https://www.cultura.kz/2017-pavillion-3-0-venice

\section{AUTHOR BIO}

Mina Cheon ( $\mathrm{PhD}, \mathrm{MFA})$ is a Korean-American global new media artist, scholar, and educator who divides her time between Baltimore, New York, and Seoul, Korea. Currently a Full-time Professor at the Maryland Institute College of Art, she serves as a Board of Directors of the New Media Caucus (NMC) and an Associate Editor of the Media-N Journal. Cheon is the writer of Shamanism and Cyberspace (Atropos Press, Dresden and New York, 2009) and have contributed writings for ArtUS, Wolgan Misool, New York Arts Magazine, and Artist Organized Art. She chaired NMC sponsored panels at the CAA in 2005 and 2012 and guest edited for Media-N with titles "Asia Effects in New Media" and "Magic and Media." Her last biennale review "Reporting the Future With New Media Art: SeMA Biennale Mediacity Seoul 2016" for Media-N, V. 12 N. 3, was translated into Korean and featured in Wolgan Misool Arts Monthly, October 2016 Issue 381. 